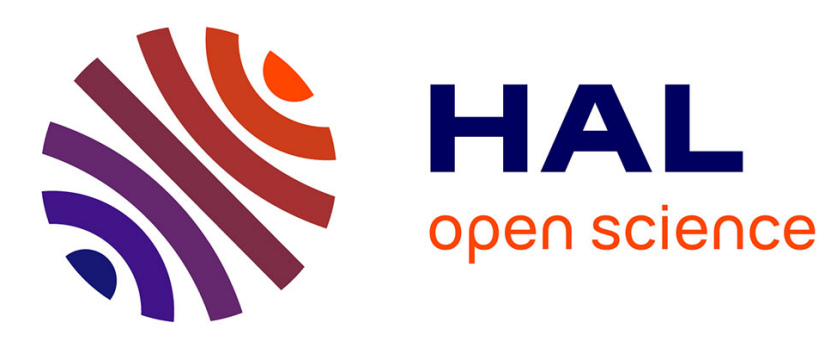

\title{
Some transition metal complexes derived from mono- and di-ethynyl perfluorobenzenes.
}

\author{
David J. Armitt, Michael I. Bruce, Maryka Gaudio, Natasha N. Zaitseva, \\ Brian W. Skelton, Allan H. White, Boris Le Guennic, Jean-François Halet, \\ Mark A. Fox, Rachel L. Roberts, et al.
}

\section{To cite this version:}

David J. Armitt, Michael I. Bruce, Maryka Gaudio, Natasha N. Zaitseva, Brian W. Skelton, et al.. Some transition metal complexes derived from mono- and di-ethynyl perfluorobenzenes.. Dalton Transactions, 2008, 47, pp.6763-75. 10.1039/b808798a . hal-00355533

\section{HAL Id: hal-00355533 https://hal.science/hal-00355533}

Submitted on 13 Sep 2013

HAL is a multi-disciplinary open access archive for the deposit and dissemination of scientific research documents, whether they are published or not. The documents may come from teaching and research institutions in France or abroad, or from public or private research centers.
L'archive ouverte pluridisciplinaire HAL, est destinée au dépôt et à la diffusion de documents scientifiques de niveau recherche, publiés ou non, émanant des établissements d'enseignement et de recherche français ou étrangers, des laboratoires publics ou privés. 


\title{
Some transition metal complexes derived from mono- and di-ethynyl perfluorobenzenes $\dagger$
}

\author{
David J. Armitt, ${ }^{a}$ Michael I. Bruce, ${ }^{* a}$ Maryka Gaudio, ${ }^{a}$ Natasha N. Zaitseva, ${ }^{a}$ Brian W. Skelton, ${ }^{b}$ \\ Allan H. White, ${ }^{b}$ Boris Le Guennic, ${ }^{c, d}$ Jean-François Halet, ${ }^{c}$ Mark A. Fox, ${ }^{e}$ Rachel L. Roberts, ${ }^{e}$ \\ František Hartlł $f$ and Paul J. Low*e
}

Received 23rd May 2008, Accepted 21st August 2008

First published as an Advance Article on the web 17th October 2008

DOI: 10.1039/b808798a

Transition metal alkynyl complexes containing perfluoroaryl groups have been prepared directly from trimethylsilyl-protected mono- and di-ethynyl perfluoroarenes by simple desilylation/metallation reaction sequences. Reactions between $\mathrm{Me}_{3} \mathrm{SiC} \equiv \mathrm{CC}_{6} \mathrm{~F}_{5}$ and $\mathrm{RuCl}(\mathrm{dppe}) \mathrm{Cp}^{\prime}\left[\mathrm{Cp}^{\prime}=\mathrm{Cp}, \mathrm{Cp} *\right]$ in the presence of $\mathrm{KF}$ in $\mathrm{MeOH}$ give the monoruthenium complexes $\mathrm{Ru}\left(\mathrm{C} \equiv \mathrm{CC}_{6} \mathrm{~F}_{5}\right)(\mathrm{dppe}) \mathrm{Cp}^{\prime}\left[\mathrm{Cp}^{\prime}=\mathrm{Cp}(\mathbf{2})\right.$; $\mathrm{Cp}^{*}(3)$ ], which are related to the known compound $\mathrm{Ru}\left(\mathrm{C} \equiv \mathrm{CC}_{6} \mathrm{~F}_{5}\right)\left(\mathrm{PPh}_{3}\right)_{2} \mathrm{Cp}(\mathbf{1})$. Treatment of $\mathrm{Me}_{3} \mathrm{SiC} \equiv \mathrm{CC}_{6} \mathrm{~F}_{5}$ with $\mathrm{Pt}_{2}(\mu-\mathrm{dppm})_{2} \mathrm{Cl}_{2}$ in the presence of $\mathrm{NaOMe}$ in $\mathrm{MeOH}$ gave the bis(alkynyl) complex $\mathrm{Pt}_{2}(\mu-\mathrm{dppm})_{2}\left(\mathrm{C} \equiv \mathrm{CC}_{6} \mathrm{~F}_{5}\right)_{2}(4)$. The $\mathrm{Pd}(0) / \mathrm{Cu}(\mathrm{I})$-catalysed reactions between $\mathrm{Au}\left(\mathrm{C} \equiv \mathrm{CC}_{6} \mathrm{~F}_{5}\right)\left(\mathrm{PPh}_{3}\right)$ and $\mathrm{Mo}(\equiv \mathrm{CBr})(\mathrm{CO})_{2} \mathrm{Tp}^{*}\left[\mathrm{Tp}^{*}=\right.$ hydridotris(3.5-dimethylpyrazoyl)borate], $\mathrm{Co}_{3}\left(\mu_{3}-\mathrm{CBr}\right)(\mu-\mathrm{dppm})(\mathrm{CO})_{7}$ or IC $\equiv \mathrm{CFc}\left[\mathrm{Fc}=\left(\eta^{5}-\mathrm{C}_{5} \mathrm{H}_{4}\right) \mathrm{FeCp}\right]$ afford $\mathrm{Mo}\left(\equiv \mathrm{CC} \equiv \mathrm{CC}_{6} \mathrm{~F}_{5}\right)(\mathrm{CO})_{2} \mathrm{Tp}^{*}(\mathbf{5})$, $\mathrm{Co}_{3}\left(\mu_{3}-\mathrm{CC} \equiv \mathrm{CC}_{6} \mathrm{~F}_{5}\right)(\mu-\mathrm{dppm})(\mathrm{CO})_{7}(\mathbf{6})$ and $\mathrm{FcC} \equiv \mathrm{CC} \equiv \mathrm{CC}_{6} \mathrm{~F}_{5}(7)$, respectively. The diruthenium complexes 1,4- $\left\{\mathrm{Cp}^{\prime}(\mathrm{PP}) \mathrm{RuC} \equiv \mathrm{C}\right\}_{2} \mathrm{C}_{6} \mathrm{~F}_{4}\left[(\mathrm{PP}) \mathrm{Cp}^{\prime}=\left(\mathrm{PPh}_{3}\right)_{2} \mathrm{Cp}(\mathbf{8})\right.$; (dppe) $\mathrm{Cp}(\mathbf{9})$; (dppe) $\left.\mathrm{Cp}^{*}(\mathbf{1 0})\right]$ are prepared from 1,4-( $\mathrm{Me}_{3} \mathrm{SiC} \equiv \mathrm{C}_{2} \mathrm{C}_{6} \mathrm{~F}_{4}$ in a manner similar to that described for the monoruthenium complexes 1-3. The non-fluorinated complexes 1,4- $\left\{\mathrm{Cp}^{\prime}(\mathrm{PP}) \mathrm{RuC} \equiv \mathrm{C}\right\}_{2} \mathrm{C}_{6} \mathrm{H}_{4}\left[(\mathrm{PP}) \mathrm{Cp}^{\prime}=\left(\mathrm{PPh}_{3}\right)_{2} \mathrm{Cp}(\mathbf{1 1})\right.$; (dppe)Cp (12); (dppe)Cp* (13)], prepared for comparison, are obtained from 1,4- $\left(\mathrm{Me}_{3} \mathrm{SiC} \equiv \mathrm{C}_{2} \mathrm{C}_{6} \mathrm{H}_{4}\right.$. Spectro-electrochemical studies of the ruthenium aryl and arylene alkynyl complexes 2-3 and 8-13, together with DFT-based computational studies on suitable model systems, indicate that perfluorination of the aromatic ring has little effect on the electronic structures of these compounds, and that the frontier orbitals have appreciable diethynylphenylene character. Molecular structure determinations are reported for the fluoroaromatic complexes 1, 2, 3, 6 and 10.

\section{Introduction}

Substitution of ring hydrogens by fluorines in aromatic compounds results in dramatic differences in properties, ${ }^{1}$ such as the marked increase in acidity of $\mathrm{C}_{6} \mathrm{~F}_{5} \mathrm{CO}_{2} \mathrm{H}$ when compared with benzoic acid $\left(K_{\mathrm{a}}=4.2 \times 10^{-4}\right.$ vs. $\left.6.2 \times 10^{-5}\right){ }^{2}$ and the tendency of the polyfluoroaromatics to undergo nucleophilic substitution. ${ }^{3}$ In addition, the introduction of strongly electron-withdrawing fluorine atoms at strategic points in a molecular structure might be expected to fine-tune electronic properties through stabilisation of

${ }^{a}$ School of Chemistry and Physics, University of Adelaide, Adelaide, South Australia, 5005

${ }^{b}$ Chemistry M313, SBBCS, University of Western Australia, Crawley, Western Australia, 6009

"Laboratoire des Sciences Chimiques de Rennes, UMR 6226 CNRSUniversité de Rennes 1, 35042, Rennes, France

${ }^{d}$ Laboratoire de Chimie, UMR CNRS 5182, École Normale Supérieure de Lyon, 46 allée d'Italie, 69364, Lyon cedex 07, France

'Department of Chemistry, Durham University, South Rd, Durham, DH1 3LE,UK.E-mail:p.j.low@durham.ac.uk;Fax: + 441913844737

${ }^{f}$ Van't Hoff Institute for Molecular Sciences, University of Amsterdam, Nieuwe Achtergracht 166, 1018WV, Amsterdam, The Netherlands

$\dagger$ CCDC reference numbers 656421, 660619-660621, 660624. For crystallographic data in CIF or other electronic format see DOI: $10.1039 / \mathrm{b} 808798 \mathrm{a}$

$\$$ Current address: Department of Chemistry, The University of Reading, Whiteknights, Reading, RG6 6AD UK. the occupied frontier orbitals or destabilisation of the unoccupied frontier orbitals. Our interest in organometallic fluorine chemistry stems from early work concerning the displacement of an aromatic $\mathrm{F}$ atom by carbonylmetal anions. ${ }^{4}$ Later, the synthesis of the $\sigma$-alkynyl complex $\mathrm{Ru}\left(\mathrm{C} \equiv \mathrm{CC}_{6} \mathrm{~F}_{5}\right)\left(\mathrm{PPh}_{3}\right)_{2} \mathrm{Cp}(\mathbf{1})^{5}$ from the corresponding chloride and pentafluorophenylacetylene, and its conversion to $\left[\mathrm{Ru}\left\{=\mathrm{C}=\mathrm{CX}\left(\mathrm{C}_{6} \mathrm{~F}_{5}\right)\right\}\left(\mathrm{PPh}_{3}\right)_{2} \mathrm{Cp}\right]^{+}(\mathrm{X}=\mathrm{H}$, alkyl, $\mathrm{Br}$, I, $\left.\mathrm{N}_{2} \mathrm{Ar}[\mathrm{Ar}=\operatorname{aryl}], \mathrm{C}_{7} \mathrm{H}_{7}\right),{ }^{6}$ were reported.

Recent studies of the redox properties of the alkynyl systems $\mathrm{M}(\mathrm{C} \equiv \mathrm{CAr})(\mathrm{PP}) \mathrm{Cp}^{\prime}\left[\mathrm{M}=\mathrm{Fe}, \mathrm{Ru}, \mathrm{Os} ; \mathrm{PP}=\left(\mathrm{PPh}_{3}\right)_{2}\right.$, dppe; $\left.\mathrm{Cp}^{\prime}=\mathrm{Cp}, \mathrm{Cp}^{*}\right]$ groups, ${ }^{7-9}$ together with the growing spectrum of synthetic methods available for the preparation of organometallic compounds featuring alkynyl-based ligands, including in situ desilylation/metalation ${ }^{10,11}$ and palladium and/or coppercatalysed cross-couplings within the metal-ligand sphere, ${ }^{8,12-15}$ have led us to reconsider the synthetic chemistry of some fluorinated analogues. Below we describe the syntheses of a variety of complexes containing perfluorinated phenyl and phenylene ring systems that illustrate the use of in situ desilylation/metallation protocols and gold-enhanced cross-coupling reactions in the preparation of organometallic derivatives of pentafluorophenylacetylene and 1,4-diethynyltetrafluorobenzene. Computational studies indicate that the electronic structures of ruthenium alkynyl complexes featuring pentafluorobenzene substituents and bimetallic complexes featuring 
1,4-diethynyltetrafluorobenzene-based bridging ligands are comparable with the analogous aromatic hydrocarbon compounds. UV-Vis-NIR spectroelectrochemical studies are consistent with the conclusions drawn from the computational work, and indicate that the ethynylaromatic ligands are redox non-innocent.

\section{Results and discussion}

\section{Complexes derived from $\mathrm{Me}_{3} \mathrm{SiC} \equiv \mathrm{CC}_{6} \mathrm{~F}_{5}$}

An earlier report has described the synthesis of $\mathrm{Ru}\left(\mathrm{C} \equiv \mathrm{CC}_{6} \mathrm{~F}_{5}\right)$ $\left(\mathrm{PPh}_{3}\right)_{2} \mathrm{Cp}(\mathbf{1})$ in $76 \%$ yield by treatment of pentafluorophenylacetylene with $\mathrm{RuCl}\left(\mathrm{PPh}_{3}\right)_{2} \mathrm{Cp}$ in the presence of sodium methoxide. ${ }^{5}$ Here, the new analogues $\mathrm{Ru}\left(\mathrm{C} \equiv \mathrm{CC}_{6} \mathrm{~F}_{5}\right)(\mathrm{dppe}) \mathrm{Cp}^{\prime}$ $\left(\mathrm{Cp}^{\prime}=\mathrm{Cp} 2, \mathrm{Cp}^{*} 3\right)$ were synthesised by reacting $\mathrm{Me}_{3} \mathrm{SiC} \mathrm{CC}_{6} \mathrm{~F}_{5}$ with $\mathrm{RuCl}(\mathrm{dppe}) \mathrm{Cp}^{\prime}$ in the presence of potassium fluoride in $63 \%$ and $54 \%$ yields, respectively (Scheme 1 ). The latter route does not require prior deprotection of the alkyne and therefore avoids the additional desilylation/purification steps associated with the isolation of the terminal acetylene from the silylated precursor. ${ }^{16}$ Elemental analyses supported by spectroscopic data confirmed the formulations of these complexes. Thus, in the ${ }^{19} \mathrm{~F}$ NMR spectra, the five fluorine nuclei resonate as three signals with relative intensities 2/1/2 from $\mathrm{AA}^{\prime} \mathrm{MXX}^{\prime}$ systems. ${ }^{17,18}$ The ortho and meta fluorines of $\mathbf{1}$ and $\mathbf{2}$ are found as multiplets at $\delta_{\mathrm{F}}-142.9,-145.6$ and $-166.3,-168.8$, respectively, and the para-fluorines are observed as triplets at $\delta_{\mathrm{F}}-165.7,-168.3$, due to coupling with the meta fluorine nuclei $[J(\mathrm{FF})=21 \mathrm{~Hz}]$. This coupling is also observed in the central parts of the AA'XX' resonance assigned to the metafluorines. Replacing the $\mathrm{Cp}$ group by $\mathrm{Cp}^{*}$ in $\mathbf{3}$ has little effect on the resonance from the ortho-fluorine atoms which is found at $\delta_{\mathrm{F}}-145.8$, although unusually, the para-fluorine resonance $\left(\delta_{\mathrm{F}}\right.$ $-169.1)$ is observed upfield of that from the meta-fluorine atoms $\left(\delta_{\mathrm{F}}-168.9\right)$. Comparison of the ${ }^{19} \mathrm{~F}$ chemical shifts for $\mathrm{HC} \equiv \mathrm{CC}_{6} \mathrm{~F}_{5}$ $[\delta-134.2(o-\mathrm{F}),-149.9(p-\mathrm{F}),-159.6(m-\mathrm{F})]$ with those of 2 shows that replacement of $\mathrm{H}$ by the $\mathrm{Ru}(\mathrm{dppe}) \mathrm{Cp}$ moiety results in shifts of $-11.4,-18.4$ and $-9.2 \mathrm{ppm}$, reflecting the electron-donating properties of the $\mathrm{Ru}$ centre.

In the ${ }^{31} \mathrm{P}$ NMR spectra, characteristic resonances at $\delta_{\mathrm{P}} 87.0$ (2) or 81.7 (3) were found. The electrospray-mass spectra (ESMS) of these complexes contained $\mathrm{M}^{+}$at $m / z 756$ (2) and 826 (3), which fragmented by loss of $\mathrm{F}$ to give ions at $m / z 738$ (2) and 808 (3), respectively. The structures of $\mathbf{2}$ and $\mathbf{3}$ were confirmed by $\mathrm{X}$-ray studies of crystals grown from dichloromethane/hexane (see below).

Two equivalents of $\mathrm{Me}_{3} \mathrm{SiC} \mathrm{CC}_{6} \mathrm{~F}_{5}$ react with $\mathrm{Pt}_{2}(\mu$ dppm $)_{2} \mathrm{Cl}_{2}{ }^{19}$ in the presence of sodium methoxide to give $\mathrm{Pt}_{2}(\mu$ $\mathrm{dppm})_{2}\left(\mathrm{C} \equiv \mathrm{CC}_{6} \mathrm{~F}_{5}\right)_{2}$ (4). The non-fluorinated analogue has been made in a similar fashion on a previous occasion. ${ }^{20}$ The IR spectrum of 4 contains a single $v(\mathrm{CC})$ band at $2079 \mathrm{~cm}^{-1}$. In the ${ }^{1} \mathrm{H}$ NMR spectrum, characteristic resonances are found for the dppm ligand at $\delta 4.62\left(\mathrm{CH}_{2}\right)$ and between $\delta 6.96$ and 7.90 $(\mathrm{Ph})$. In the ${ }^{31} \mathrm{P}$ NMR spectrum the phosphine ligands give rise to a resonance at $\delta 2.13$, with evident coupling to ${ }^{195} \mathrm{Pt}[J(\mathrm{PPt})=$ $2816 \mathrm{~Hz}$. In the ${ }^{19} \mathrm{~F}$ NMR spectrum the usual three multiplets are found at $\delta_{\mathrm{F}}-143.1,-165.7$ and -168.2 for the ortho-, paraand meta-fluorines, respectively. The ES-MS contains $[\mathrm{M}+\mathrm{H}]^{+}$at $m / z$ 1541. As with the synthesis of $\mathbf{1}$, no evidence was found to suggest that the para-fluorine of $\mathbf{4}$ underwent nucleophilic attack by the methoxide present in the reaction mixture. This may be for kinetic reasons, with the metallation reaction and precipitation of the product taking place prior to fluoride substitution, but could also be due to electron-donation from the metal-acetylide fragment increasing the electron density at the para-carbon of the fluoroaromatic substituent.

\section{Complexes derived from $\mathrm{Au}\left(\mathrm{C} \equiv \mathrm{CC}_{6} \mathrm{~F}_{5}\right) \mathrm{PPh}_{3}$}

The $\mathrm{Pd}(0) / \mathrm{Cu}(\mathrm{I})$-catalysed reaction between phosphine-gold(I) alkynyls and $\mathrm{C}\left(\mathrm{sp}^{2}\right.$ or $\left.\mathrm{sp}^{3}\right)-\mathrm{X}(\mathrm{X}=\mathrm{Br}$, I) bonds has recently been developed as a base-free analogue of the Sonogashira reaction, which is useful in the preparation of novel metal-containing alkynyl and poly-ynyl derivatives. ${ }^{16}$ Using this methodology, reaction between $\mathrm{Au}\left(\mathrm{C} \equiv \mathrm{CC}_{6} \mathrm{~F}_{5}\right)\left(\mathrm{PPh}_{3}\right)$ and $\mathrm{Mo}(\equiv \mathrm{CBr})(\mathrm{CO})_{2} \mathrm{Tp}^{*}\left[\mathrm{Tp}^{*}=\right.$ hydridotris(3.5-dimethylpyrazoyl)borate] gave the pentafluorophenyl-terminated $\mathrm{C}_{3}$ complex, $\mathrm{Mo}\left(\equiv \mathrm{CC} \equiv \mathrm{CC}_{6} \mathrm{~F}_{5}\right)(\mathrm{CO})_{2} \mathrm{Tp}^{*}(\mathbf{5})(18 \%)$ (Scheme 2). Complex 5 was characterised by the usual array of spectroscopic methods, with ES-MS containing $[\mathrm{M}+\mathrm{Na}]^{+}$at $m / z 677$. The IR spectrum of 5 displays two $v(C C)$ bands at 2110 and $2061 \mathrm{~cm}^{-1}$ and two terminal $v(\mathrm{CO})$ bands at 2006 and $1926 \mathrm{~cm}^{-1}$. In the ${ }^{19} \mathrm{~F}$ NMR spectrum the ortho- and meta-fluorines are found at $\delta_{\mathrm{F}}-136.8$ and -163.9 , with
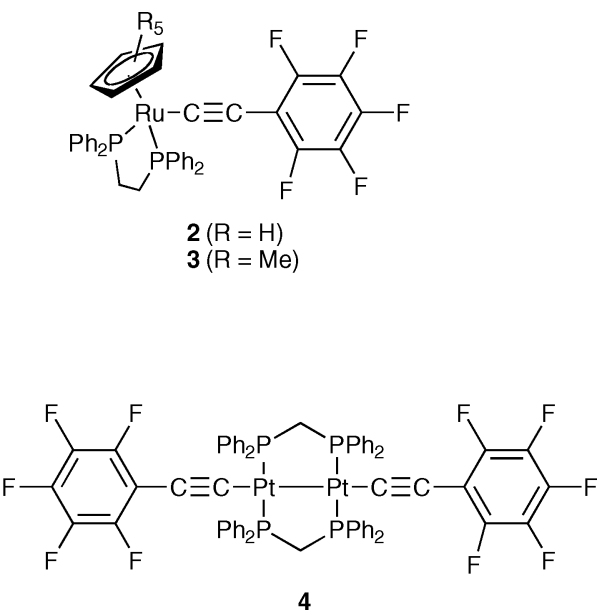

Scheme 1 


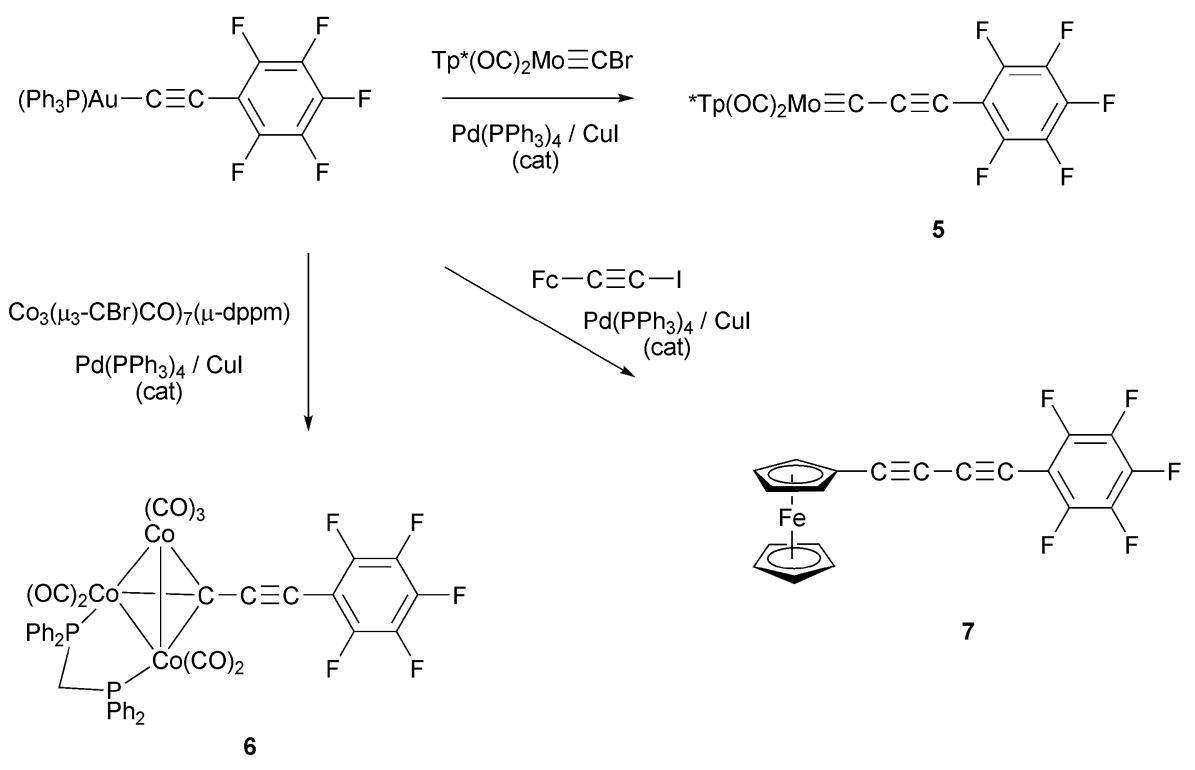

Scheme 2

the para-fluorine giving a triplet $\delta_{\mathrm{F}}-153.7[J(\mathrm{FF})=20 \mathrm{~Hz}]$. The broadening of each line within this triplet suggests that there is also an unresolved coupling between the para- and ortho-fluorine nuclei.

The $\mathrm{Pd}(0) / \mathrm{Cu}(\mathrm{I})$-catalysed reaction between $\mathrm{Co}_{3}\left(\mu_{3}-\mathrm{CBr}\right)(\mu$ dppm $)(\mathrm{CO})_{7}$ and $\mathrm{Au}\left(\mathrm{C} \equiv \mathrm{CC}_{6} \mathrm{~F}_{5}\right)\left(\mathrm{PPh}_{3}\right)$ afforded dark red $\mathrm{Co}_{3}\left(\mu_{3}-\right.$ $\left.\mathrm{CC} \equiv \mathrm{CC}_{6} \mathrm{~F}_{5}\right)(\mu-\mathrm{dppm})(\mathrm{CO})_{7}(6)(36 \%)$ (Scheme 2), characterised by IR $\left[v(\mathrm{CC})\right.$ at $2122 \mathrm{~cm}^{-1}$, terminal $v(\mathrm{CO})$ between 2062 and $\left.1976 \mathrm{~cm}^{-1}\right]$ and multinuclear NMR $\left[\mathrm{CH}_{2}\right.$ at $\delta_{\mathrm{H}} 3.49,4.24, \delta_{\mathrm{C}} 29.60$, one $\mathrm{C}(\mathrm{sp})$ at $\delta_{\mathrm{C}} 72.17, \mathrm{Ph}$ between $\delta_{\mathrm{H}} 7.18-7.73, \delta_{\mathrm{C}} 128.73-132.43$, $\operatorname{dppm}\left(\delta_{\mathrm{P}} 34.7\right)$ and $\mathrm{C}_{6} \mathrm{~F}_{5}\left[\delta_{\mathrm{F}}-139.8,-158.4,-165.5(o-, p-, m-\mathrm{F})\right]$ spectroscopies, and ES-MS, with $[\mathrm{M}+\mathrm{Na}]^{+}$and $[\mathrm{M}+\mathrm{H}]^{+}$at $m / z 983$ and 961, respectively, being observed. In the negative ion ES-MS, $[\mathrm{M}-\mathrm{H}]^{-}$at $m / z 959$ was observed. The structure of the complex was also established by a single crystal X-ray diffraction study.

The Cadiot-Chodkiewicz reaction, in which a terminal alkyne $\mathrm{RC} \equiv \mathrm{CH}$ and a haloalkyne $\mathrm{XC} \equiv \mathrm{CR}^{\prime}$ are cross-coupled in the presence of a copper catalyst, is a well-known route to the preparation of differentially substituted 1,4-buta-1,3-diynes, $\mathrm{RC} \equiv \mathrm{CC} \equiv \mathrm{CR}^{\prime}{ }^{21}$ The reaction between $\mathrm{Au}\left(\mathrm{C} \equiv \mathrm{CC}_{6} \mathrm{~F}_{5}\right)\left(\mathrm{PPh}_{3}\right)$ and iodoethynylferrocene, $\mathrm{IC} \equiv \mathrm{CFc}$, gives 1-ferrocenyl-4-pentafluorophenylbuta-1,3diyne, $\mathrm{FcC} \equiv \mathrm{CC} \equiv \mathrm{CC}_{6} \mathrm{~F}_{5}$ (7), accompanied by some $\mathrm{FcC} \equiv \mathrm{CC} \equiv \mathrm{CFc}$. The composition of the former compound was readily established from elemental analysis and the usual spectroscopic data. Thus in the IR spectrum a single $v(\mathrm{CC})$ band was observed at $2220 \mathrm{~cm}^{-1}$. In the ${ }^{13} \mathrm{C}$ NMR spectrum, resonances at $\delta_{\mathrm{C}} 62.10,69.53,86.86$ and 99.55 are assigned to the carbon nuclei of the butadiyne fragment. In the ${ }^{19} \mathrm{~F}$ NMR two multiplets at $\delta_{\mathrm{F}}-137.7$ and -163.8 and a triplet at $\delta_{\mathrm{F}}-153.9$ are found for the $o-, m$ - and $p$-fluorines, respectively. The ES-MS contains $\mathbf{M}^{+}$at $m / z 400$.

\section{Ruthenium complexes derived from 1,4-( $\left.\mathrm{Me}_{3} \mathrm{SiC} \equiv \mathrm{C}\right)_{2} \mathrm{C}_{6} \mathrm{~F}_{4}$}

The pentafluorophenyl ring systems in complexes such as $\mathbf{1}-\mathbf{3}$ are inert toward substitution reactions with common nucleophiles, and our attempts to synthesise bis-metalla-1,4-diethynyltetrafluorobenzenes by reacting monometallic (pentafluorophenyl)ethynyl complexes 1-3 with alkynyl anions have been so far unsuccessful. Hence 1,4-bis[(trimethylsilyl)ethynyl]tetrafluorobenzene ${ }^{16,22}$ was treated with $\mathrm{RuCl}(\mathrm{PP}) \mathrm{Cp}^{\prime}$ [where $\mathrm{PP}=\left(\mathrm{PPh}_{3}\right)_{2}$, dppe; $\left.\mathrm{Cp}^{\prime}=\mathrm{Cp}, \mathrm{Cp}^{*}\right]$ in the presence of $\mathrm{KF}$ to give the diruthenium complexes 1,4- $\left\{\mathrm{Cp}^{\prime}(\mathrm{PP}) \mathrm{Ru}(\mathrm{C} \equiv \mathrm{C})\right\}_{2} \mathrm{C}_{6} \mathrm{~F}_{4}\left[\mathrm{PP}=\left(\mathrm{PPh}_{3}\right)_{2}, \mathrm{Cp}^{\prime}=\mathrm{Cp}\right.$ (8), $\mathrm{PP}=$ dppe, $\left.\mathrm{Cp}^{\prime}=\mathrm{Cp}(\mathbf{9}), \mathrm{Cp}^{*}(\mathbf{1 0})\right]$ in 60,26 and $63 \%$ yields, respectively (Scheme 3 ). Elemental analyses and ES-MS confirmed the formulations of these complexes with $\mathbf{M}^{+}$found at $m / z 1578$ (for 8) and $1326(9)$, with $[\mathrm{M}+\mathrm{H}]^{+}$being obtained as the highest molecular weight ion in the MS of the most electron-rich example, 10. For each compound 8-10 the IR spectra contain two $v(\mathrm{CC})$ bands, which were closely spaced, between 2072 and $2032 \mathrm{~cm}^{-1}$. In the ${ }^{1} \mathrm{H}$ NMR spectra, the usual resonances for the $\mathrm{Cp}$ ligands are found at $\delta_{\mathrm{H}} 4.86(8)$ and $4.71(\mathbf{9})$, and for $\mathrm{Cp}^{*}$ at $\delta 1.68(\mathbf{1 0})$. The ${ }^{13} \mathrm{C}$ NMR of 10 contains resonances at $\delta_{\mathrm{C}} 10.7$ and $93.7\left(\mathrm{Cp}^{*}\right)$. In the ${ }^{31} \mathrm{P}$ NMR spectra, characteristic resonances at $\delta_{\mathrm{P}} 51.7(\mathbf{8}), 86.7$ (9) and 80.9 (10) were found. The ${ }^{19} \mathrm{~F}$ NMR spectra each contain only one resonance at $\delta_{\mathrm{F}}-147.0(\mathbf{8}),-147.8(9)$ and $-148.0(\mathbf{1 0})$, as expected for a symmetrically disubstituted $\mathrm{C}_{6} \mathrm{~F}_{4}$ group.

\section{Ruthenium complexes derived from $1,4-\left(\mathrm{Me}_{3} \mathrm{SiC} \equiv \mathrm{C}\right)_{2} \mathrm{C}_{6} \mathrm{H}_{4}$}

For purposes of comparison with the fluorinated complexes here, it was desirable to examine the hydrocarbon analogues $\mathrm{Ru}(\mathrm{C} \equiv \mathrm{CPh})(\mathrm{PP}) \mathrm{Cp}^{\prime}$ and $1,4-\left\{\mathrm{Cp}^{\prime}(\mathrm{PP}) \mathrm{RuC} \equiv \mathrm{C}\right\}_{2} \mathrm{C}_{6} \mathrm{H}_{4}$. All three monoruthenium complexes $\mathrm{Ru}(\mathrm{C} \equiv \mathrm{CPh})(\mathrm{PP}) \mathrm{Cp}^{\prime}$ have been reported elsewhere. , 23,24 Of the diruthenium complexes only the very insoluble compound $1,4-\left\{\mathrm{Cp}\left(\mathrm{PPh}_{3}\right)_{2} \mathrm{RuC} \equiv \mathrm{C}\right\}_{2} \mathrm{C}_{6} \mathrm{H}_{4}$ (11) has been prepared previously. ${ }^{25}$ The more soluble systems 1,4$\{\mathrm{Cp}(\text { dppe }) \mathrm{RuC} \equiv \mathrm{C}\}_{2} \mathrm{C}_{6} \mathrm{H}_{4}(\mathbf{1 2})$ and $1,4-\{\mathrm{Cp} *(\text { dppe }) \mathrm{RuC} \equiv \mathrm{C}\}_{2} \mathrm{C}_{6} \mathrm{H}_{4}$ (13) were readily prepared from reactions of 1,4-( $\left.\mathrm{Me}_{3} \mathrm{SiC} \equiv \mathrm{C}\right)_{2} \mathrm{C}_{6} \mathrm{H}_{4}$ and two molar equivalents of the appropriate chloride precursor $\mathrm{RuCl}(\mathrm{PP}) \mathrm{Cp}^{\prime}$ in the presence of $\mathrm{KF}$ (Scheme 3). The characterisation of these compounds was straightforward, and details of 
<smiles>[X]c1c([X])c(C#CCSC)c([X])c([X])c1C#CC</smiles>

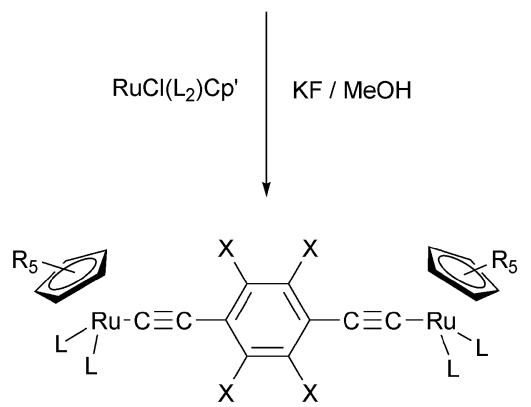

$\begin{array}{cccc} & \mathrm{X} & \mathrm{L}_{2} & \mathrm{R} \\ 8 & \mathrm{~F} & \left(\mathrm{PPh}_{3}\right)_{2} & \mathrm{H} \\ 9 & \mathrm{~F} & \text { dppe } & \mathrm{H} \\ 10 & \mathrm{~F} & \text { dppe } & \mathrm{Me} \\ 11 & \mathrm{H} & \left(\mathrm{PPh}_{3}\right)_{2} & \mathrm{H} \\ 12 & \mathrm{H} & \text { dppe } & \mathrm{H} \\ 13 & \mathrm{H} & \text { dppe } & \mathrm{Me}\end{array}$

Scheme 3

the elemental analytical and spectroscopic results are given in the Experimental section.

\section{Molecular structures}

The structures of $\mathbf{1}, \mathbf{2}, \mathbf{3}, \mathbf{6}$ and $\mathbf{1 0}$ have been determined by single-crystal X-ray diffraction studies $\uparrow$ and molecules of these complexes are depicted in Fig. 1-5. Table 1 contains selected structural parameters for all but $\mathbf{6}$, for which selected data are given in the caption to the associated Figure, whilst Table 2 summarises

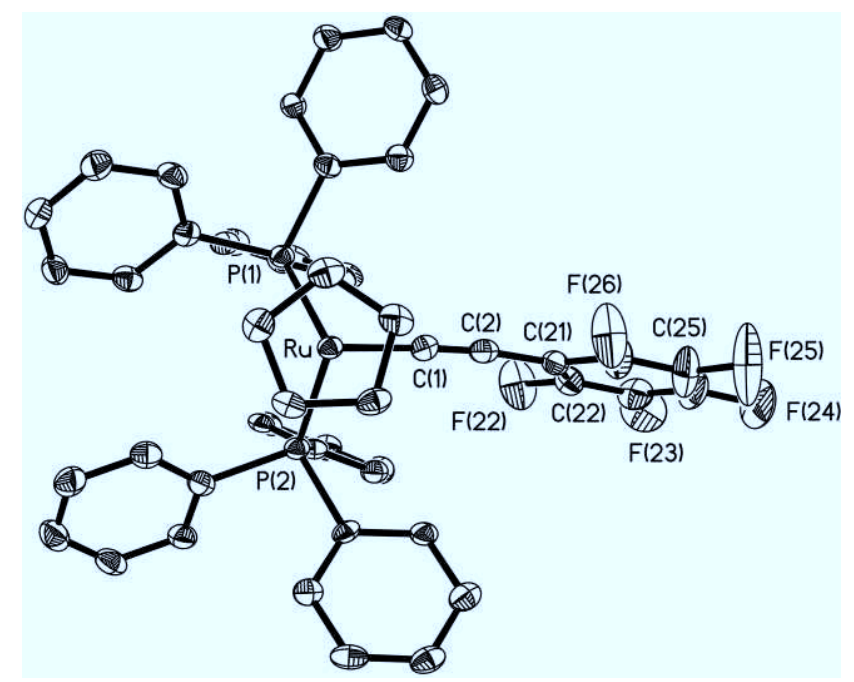

Fig. 1 Projection of a single molecule of $\mathrm{Ru}\left(\mathrm{C} \equiv \mathrm{CC}_{6} \mathrm{~F}_{5}\right)\left(\mathrm{PPh}_{3}\right)_{2} \mathrm{Cp}(\mathbf{1})$. In this, and subsequent plots, hydrogen atoms have been omitted for clarity.

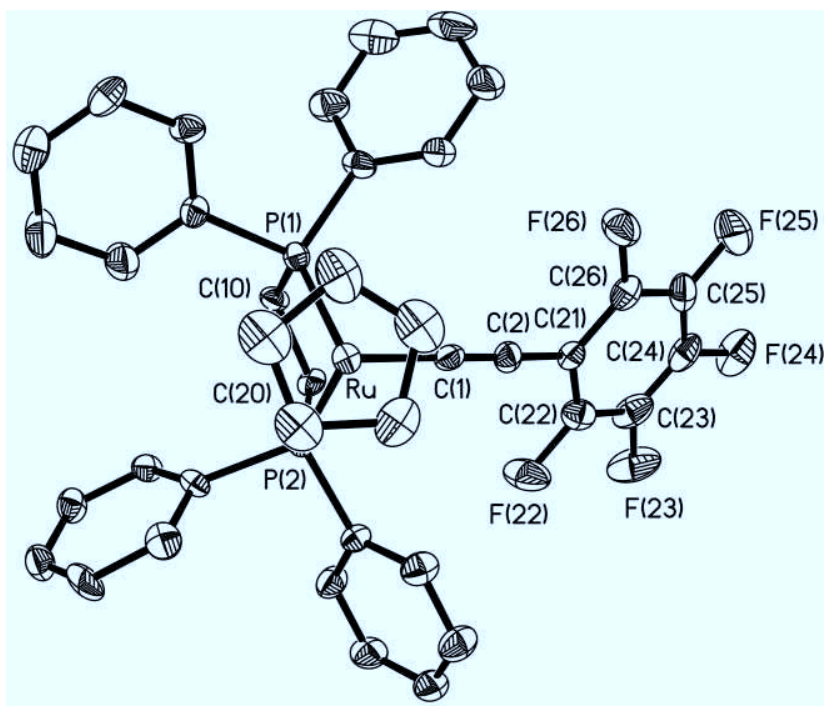

Fig. 2 Projection of a single molecule of $\mathrm{Ru}\left(\mathrm{C} \equiv \mathrm{CC}_{6} \mathrm{~F}_{5}\right)(\mathrm{dppe}) \mathrm{Cp}(\mathbf{2})$.

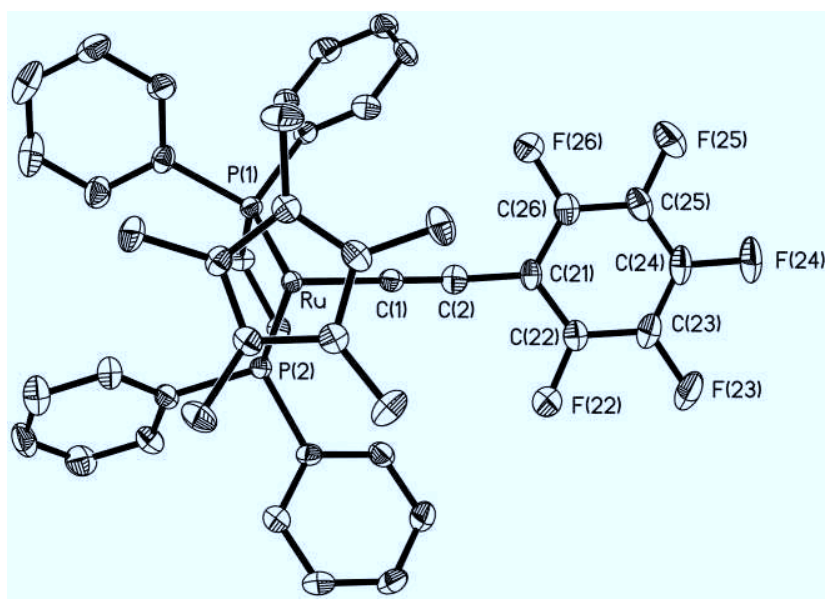

Fig. 3 Projection of a single molecule of $\mathrm{Ru}\left(\mathrm{C} \equiv \mathrm{CC}_{6} \mathrm{~F}_{5}\right)(\mathrm{dppe}) \mathrm{Cp} *(3)$.

details of the data collection. The $\mathrm{Ru}(\mathrm{dppe}) \mathrm{Cp}^{\prime}$ fragments have the expected near-octahedral geometry, with $\mathrm{Ru}-\mathrm{P}$ bond distances of 2.238(2)-2.2694(8) $\AA$ and $\mathrm{Ru}-\mathrm{C}(\mathrm{Cp}) 2.215(7)-2.269(3) \AA$. Along the carbon chain of $2 \mathrm{C}(1)-\mathrm{C}(2)$ is $1.205(9) \AA$ and $\mathrm{C}(2)-\mathrm{C}(21)$ is $1.432(9) \AA$, while in $3 \mathrm{C}(1)-\mathrm{C}(2)$ is $1.217(5) \AA$ and $\mathrm{C}(2)-\mathrm{C}(21)$ is $1.442(5) \AA$. The $\mathrm{Ru}-\mathrm{C}(1)$ distance in 2 is $1.982(7) \AA$, similar to that reported for $\mathrm{Ru}\left(\mathrm{C} \equiv \mathrm{CC} \equiv \mathrm{CSiMe}_{3}\right)(\mathrm{dppe}) \mathrm{Cp} *[1.983(2) \AA] ;{ }^{26}$ in 3 the $\mathrm{Ru}-\mathrm{C}(1)$ distance is 2.000(3) $\AA$. The carbon chain of $\mathbf{2}$ is significantly less distorted than that of $\mathbf{3}$, with angles at $\mathrm{C}(1,2)$ of $178.7(6)$ and $177.2(7)^{\circ}$ (for 2) compared with values of 168.9(3) and $170.2(3)^{\circ}$ for 3 . In 10 the $\mathrm{Ru}(\mathrm{dppe}) \mathrm{Cp}$ fragment has the expected geometry, with $\mathrm{Ru}-\mathrm{P}(1,2) 2.2542(7)$ and 2.2607(7) $\AA$ and $\mathrm{Ru}-\mathrm{C}(\mathrm{Cp}) 2.223(3)-2.264(3) \AA$; the $\mathrm{C}(1)-\mathrm{C}(2), \mathrm{C}(2)-\mathrm{C}(3)$ separations are 1.221(3), 1.427(3) $\AA$ and the $\mathrm{Ru}-\mathrm{C}(1)$ distance is $1.996(2) \AA$. The carbon chain is again somewhat distorted, with angles at $\mathrm{C}(1,2)$ of $172.6(2)$ and $172.2(3)^{\circ}$, respectively. Surprisingly, compound $\mathbf{1 0}$ appears to represent the first bimetallic ruthenium complex of general type $\mathrm{L}_{n} \mathrm{RuC} \equiv \mathrm{CArC} \equiv \mathrm{CRuL}_{n}$ to be structurally characterised.

Comparison of closely related complexes containing $\mathrm{Ph}$ and $\mathrm{C}_{6} \mathrm{~F}_{5}$ groups shows that there are few significant structural 


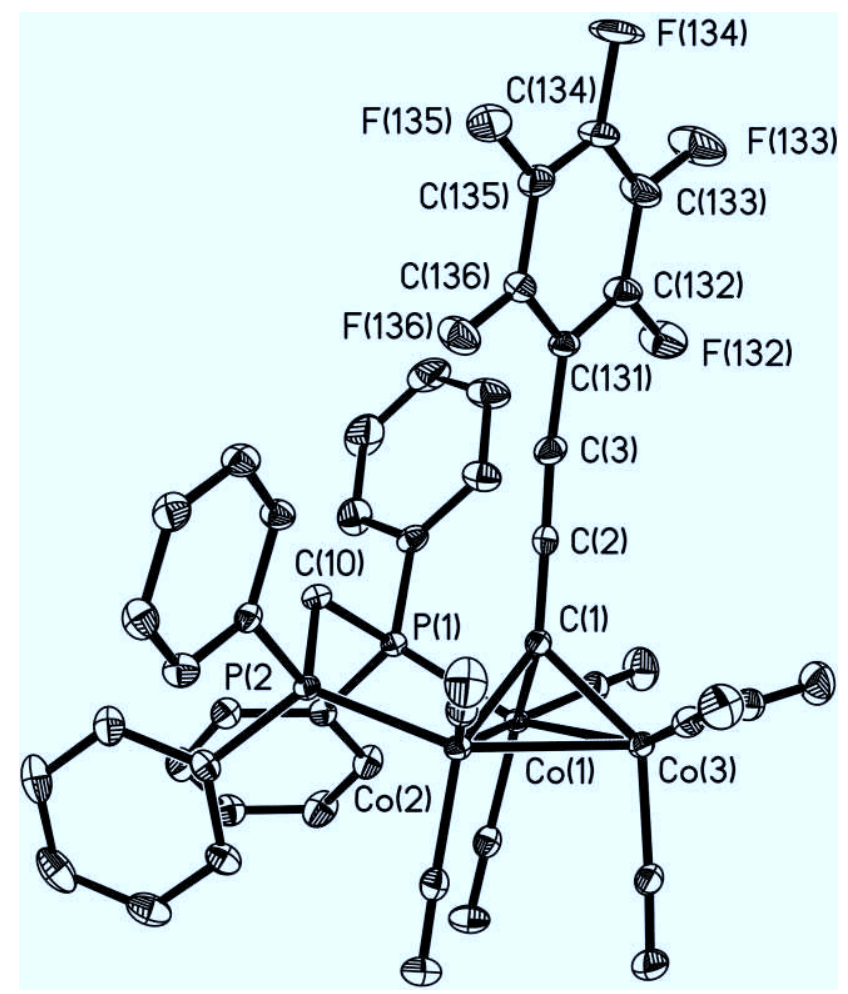

Fig. 4 Projection of molecule 1 of $\mathrm{Co}_{3}\left(\mu_{3}-\mathrm{CC} \equiv \mathrm{CC}_{6} \mathrm{~F}_{5}\right)(\mu$-dppm $)(\mathrm{CO})_{7}$ (6). Selected structural data: Bond distances $(\AA) \operatorname{Co}(1)-\operatorname{Co}(2,3) 2.4781(5)$, 2.4810(4), $\mathrm{Co}(2)-\mathrm{Co}(3)$ 2.4805(4), $\operatorname{Co}(n)-\mathrm{P}(n) \quad(n=1,2)$ 2.2014(5), 2.2035(4), $\quad \mathrm{Co}(1)-\mathrm{C}(1) \quad 1.900(1), \quad \mathrm{Co}(2)-\mathrm{C}(1) \quad 1.914(2), \quad \mathrm{Co}(3)-\mathrm{C}(1)$ 1.947(1), C(1)-C(2) 1.403(2), C(2)-C(3) 1.213(2), C(3)-C(131) 1.428(2), $\mathrm{C}(13 \mathrm{n})-\mathrm{C}(13 n+1)$ (av.) 1.385(9), $\mathrm{C}(13 n)-\mathrm{F}(13 n)$ (av.) 1.343(3) $\AA$. Bond angles $\left({ }^{\circ}\right) \mathrm{Co}(1)-\mathrm{C}(1)-\mathrm{C}(2)$ 136.3(1), $\mathrm{Co}(2)-\mathrm{C}(1)-\mathrm{C}(2)$ 131.4(1), $\mathrm{Co}(3)-\mathrm{C}(1)-\mathrm{C}(2)$ 127.2(1), C(1)-C(2)-C(3) 179.1(2), C(2)-C(3)-C(131) 175.8(2), C(3)-C(131)-C(132) 121.9(1), C(3)-C(131)-C(136) 121.8(1) . Molecule 2 is similar, differing only in the aromatic ring orientations.

differences. Considering the three pairs: $\mathrm{Ru}\left(\mathrm{C} \equiv \mathrm{CC}_{6} \mathrm{X}_{5}\right)(\mathrm{PP}) \mathrm{Cp}^{\prime}$ $\left[\mathrm{X}=\mathrm{H}, \mathrm{F} ;(\mathrm{PP}) \mathrm{Cp}^{\prime}=\left(\mathrm{PPh}_{3}\right)_{2} \mathrm{Cp}\right.$ and $(\mathrm{dppe}) \mathrm{Cp}$, (dppe)Cp*, the $\mathrm{Ru}-\mathrm{P}$ distances are experimentally the same in each pair, although they may differ with ligand set..$^{8,23,24}$ The $\mathrm{Ru}-\mathrm{C}(1)$ distance is longer in the phenylethynyl derivatives than in the

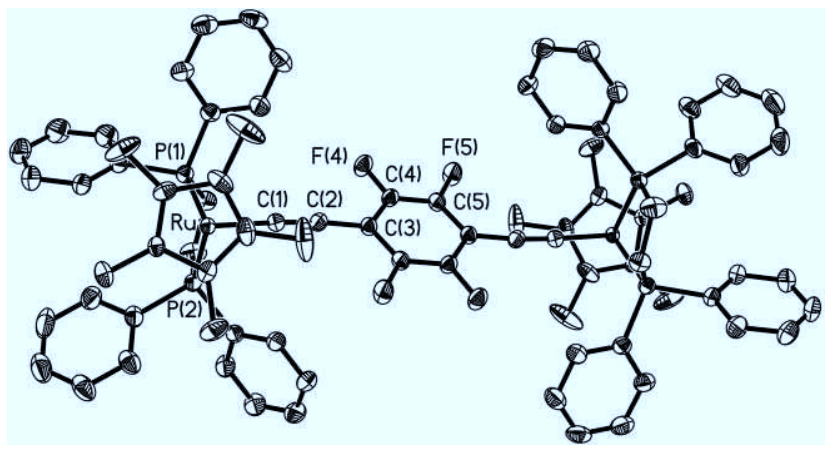

Fig. 5 Projection of a molecule of $1,4-\left\{C p^{*}(\text { dppe }) \mathrm{Ru}(\mathrm{C} \equiv \mathrm{C})\right\}_{2} \mathrm{C}_{6} \mathrm{~F}_{4}(\mathbf{1 0})$.

$\mathrm{C}_{6} \mathrm{~F}_{5}$ analogues [2.017(5), 2.009(3), 2.011(4) $(\mathrm{X}=\mathrm{H})$ vs. 1.991(6), $1.982(7), 2.000(3) \AA(\mathrm{X}=\mathrm{F})]$, while the $\mathrm{C}(2)-\mathrm{C}(21)$ distances are also shorter in two of the $\mathrm{C}_{6} \mathrm{~F}_{5}$ compounds, but longer in the $\mathrm{Cp}^{*}$ complex [1.463(8), 1.444(5), 1.431(5) $(\mathrm{X}=\mathrm{H})$ vs. 1.421(9), $1.432(9), 1.442(5) \AA(\mathrm{X}=\mathrm{F})]$. However, the differences are only marginally significant. Within the $\mathrm{C}_{6} \mathrm{X}_{5}$ ring, average $\mathrm{C}-\mathrm{C}$ separations are 1.395(8), 1.396(5), 1.373(9) $(\mathrm{X}=\mathrm{H})$ vs. 1.380(6), $1.373(10), 1.383(11) \AA(\mathrm{X}=\mathrm{F})$.

In 6 (Fig. 4), the carbon chains of the two independent molecules are essentially linear $\left[\mathrm{C}(2)-\mathrm{C}(3)-\mathrm{C}(131) 175.8(2), 173.5(2)^{\circ}\right]$ with $\mathrm{C}(1)-\mathrm{C}(2)[1.403(2), 1.404(2) \AA]$ consistent with a carbon-carbon single bond and $\mathrm{C}(2)-\mathrm{C}(3)[1.213(2), 1.208(2) \AA]$ with $\mathrm{C}(1)-\mathrm{C}(2)$ triple bond. The $\mathrm{Co}_{3}(\mu$-dppm $)(\mathrm{CO})_{7}$ clusters are similar to those found in many related examples, ${ }^{15,27-30}$ with $\mathrm{Co}-\mathrm{Co} 2.4763(4)$ 2.4938(4), Co-P 2.2014(5)-2.2108(4) and Co-C(1) 1.893(2)$1.914(2)$ and 1.940(1), 1.947(1) $\AA$, the latter involving $\mathrm{Co}(3)$, which is not attached to the dppm ligand.

\section{Electrochemistry}

Extensive studies of the redox properties of arylalkynyl complexes containing $\mathrm{M}(\mathrm{PP}) \mathrm{Cp}^{\prime}\left[\mathrm{M}=\mathrm{Fe}, \mathrm{Ru} ; \mathrm{PP}=\left(\mathrm{PPh}_{3}\right)_{2}\right.$, dppe; $\mathrm{Cp}^{\prime}=$ $\mathrm{Cp}, \mathrm{Cp}^{*}$ (not all combinations)] fragments have been made, with complementary spectroscopic and computational work used to analyse the physical and electronic structure of the redox-related species. $^{7-9}$ In the case of arylalkynyl compounds of the Group 8 metals, the extensive mixing of the metal and alkynyl frontier orbitals leads to a significant degree of carbon ligand character in

Table 1 Selected bond parameters for 1-3 and $\mathbf{1 0}$

\begin{tabular}{|c|c|c|c|c|}
\hline Complex & 1 & 2 & 3 & 10 \\
\hline \multicolumn{5}{|l|}{ Bond distances/Å } \\
\hline $\mathrm{Ru}-\mathrm{P}(1)$ & $2.295(2)$ & $2.238(2)$ & $2.2694(8)$ & $2.2542(7)$ \\
\hline $\mathrm{Ru}-\mathrm{P}(2)$ & $2.282(2)$ & $2.260(2)$ & $2.2592(8)$ & $2.2607(7)$ \\
\hline $\mathrm{Ru}-\mathrm{C}(\mathrm{Cp})$ & $2.232(5)-2.261(6)$ & $2.215(7)-2.250(8)$ & $2.224(3)-2.269(3)$ & $2.223(3)-2.264(3)$ \\
\hline (Av.) & $2.244(11)$ & $2.234(14)$ & $2.25(2)$ & $2.250(16)$ \\
\hline $\mathrm{Ru}-\mathrm{C}(1)$ & $1.991(6)$ & $1.982(7)$ & $2.000(3)$ & $1.996(2)$ \\
\hline$C(1)-C(2)$ & $1.225(9)$ & $1.205(9)$ & $1.217(5)$ & $1.221(3)$ \\
\hline $\mathrm{C}(2)-\mathrm{C}(21)$ & $1.421(9)$ & $1.432(9)$ & $1.442(5)$ & $1.427(3)$ \\
\hline $\mathrm{C}(2 \mathrm{n})-\mathrm{F}(2 \mathrm{n})$ & $1.329(8)-1.362(12)$ & $1.329(9)-1.353(10)$ & $1.338(5)-1.352(5)$ & $1.342(3), 1.356(3)$ \\
\hline (Av.) & $1.344(14)$ & $1.340(10)$ & $1.344(6)$ & $1.349(10)$ \\
\hline \multicolumn{5}{|l|}{ Bond angles $/^{\circ}$} \\
\hline $\mathrm{P}(1)-\mathrm{Ru}-\mathrm{P}(2)$ & $100.31(5)$ & $83.48(6)$ & $82.44(3)$ & $82.62(3)$ \\
\hline $\mathrm{P}(1)-\mathrm{Ru}-\mathrm{C}(1)$ & $92.3(2)$ & $87.2(2)$ & $89.12(9)$ & $86.38(7)$ \\
\hline $\mathrm{P}(2)-\mathrm{Ru}-\mathrm{C}(1)$ & $87.4(2)$ & $81.6(2)$ & $87.62(9)$ & $85.45(7)$ \\
\hline $\mathrm{Ru}-\mathrm{C}(1)-\mathrm{C}(2)$ & $173.0(5)$ & $178.7(6)$ & $168.9(3)$ & $172.6(2)$ \\
\hline $\mathrm{C}(1)-\mathrm{C}^{\prime}(2)-\mathrm{C}(21)$ & $169.2(6)$ & $177.2(7)$ & $170.2(3)$ & $172.2(3)$ \\
\hline
\end{tabular}


Table 2 Crystal data and refinement details $\uparrow$

\begin{tabular}{|c|c|c|c|c|c|}
\hline Complex & 1 & 2 & 3 & 6 & 10 \\
\hline Formula & $\mathrm{C}_{49} \mathrm{H}_{35} \mathrm{~F}_{5} \mathrm{P}_{2} \mathrm{Ru} \cdot 0.5 \mathrm{C}_{6} \mathrm{H}_{6}$ & $\mathrm{C}_{39} \mathrm{H}_{29} \mathrm{~F}_{5} \mathrm{P}_{2} \mathrm{Ru}$ & $\mathrm{C}_{44} \mathrm{H}_{39} \mathrm{~F}_{5} \mathrm{P}_{2} \mathrm{Ru}$ & $\mathrm{C}_{41} \mathrm{H}_{22} \mathrm{Co}_{3} \mathrm{~F}_{5} \mathrm{O}_{7} \mathrm{P}_{2}$ & $\mathrm{C}_{82} \mathrm{H}_{78} \mathrm{~F}_{4} \mathrm{P}_{4} \mathrm{Ru}_{2}$ \\
\hline MW & 920.88 & 755.67 & 825.8 & 960.32 & 1465.55 \\
\hline Crystal system & Monoclinic & Orthorhombic & Monoclinic & Triclinic & Monoclinic \\
\hline Space group & $P 2_{1} / n$ & $P 2_{1} 2_{1} 2_{1}$ & $P 2_{1} / c$ & $P \overline{1}$ & $P 2_{1} / n$ \\
\hline$a / \AA ̊$ & $10.1626(7)$ & $8.988(1)$ & $8.605(1)$ & $11.617(1)$ & $10.982(1)$ \\
\hline$b / \AA ̊$ & $24.5128(2)$ & $15.065(2)$ & $25.438(3)$ & $17.643(2)$ & $18.486(2)$ \\
\hline$c / \AA$ & 17.0993(8) & $23.420(3)$ & $17.212(2)$ & $19.108(3)$ & $17.193(2)$ \\
\hline$\alpha /^{\circ}$ & - & - & - & $97.855(9)$ & - \\
\hline$\beta /^{\circ}$ & $96.323(5)$ & - & $100.864(2)$ & $91.445(11)$ & $93.839(2)$ \\
\hline$\gamma /{ }^{\circ}$ & - & - & - & $93.438(7)$ & - \\
\hline$V / \AA^{3}$ & $4233.8(4)$ & $3171.2(7)$ & $3700.1(7)$ & $3870.4(8)$ & $3482.6(6)$ \\
\hline$Z$ & 4 & 4 & 4 & 4 & 2 \\
\hline$\rho_{\mathrm{c}} / \mathrm{g} \mathrm{cm}^{-3}$ & $1.44_{5}$ & $1.58_{3}$ & $1.48_{2}$ & $1.64_{8}$ & $1.39_{8}$ \\
\hline $2 \theta_{\max } /^{\circ}$ & 58 & 58 & 58 & 68 & 62 \\
\hline$\mu(\mathrm{Mo}-K \alpha) / \mathrm{mm}^{-1}$ & 0.50 & 0.65 & 0.57 & 1.43 & 0.58 \\
\hline$T_{\min / \max }$ & 0.92 & 0.91 & 0.91 & 0.92 & 0.92 \\
\hline Crystal dimensions $/ \mathrm{mm}$ & $0.26 \times 0.21 \times 0.05$ & $0.23 \times 0.15 \times 0.09$ & $0.36 \times 0.13 \times 0.07$ & $0.38 \times 0.28 \times 0.24$ & $0.48 \times 0.32 \times 0.12$ \\
\hline$N_{\text {tot }}$ & 92469 & 30061 & 33123 & 76417 & 38966 \\
\hline$N\left(R_{\text {int }}\right)$ & $11272(0.067)$ & $4570(0.048)$ & $9336(0.043)$ & $29976(0.024)$ & $11272(0.033)$ \\
\hline$N_{\mathrm{o}}$ & 11272 & 4127 & 7506 & 20530 & 8907 \\
\hline$R$ & 0.068 & 0.048 & 0.044 & $0.032(R 1)$ & 0.036 \\
\hline$R_{\mathrm{w}}$ & 0.085 & 0.067 & 0.080 & $0.083(w R 2)$ & 0.077 \\
\hline$T / \mathrm{K}$ & 100 & 170 & 170 & 100 & 150 \\
\hline
\end{tabular}

the HOMOs of the resulting radical cations. ${ }^{8,9}$ Table 3 collects electrochemical data for the ruthenium $\sigma$-alkynyl complexes 2-3, 8-13 and the monoruthenium complexes $\mathrm{Ru}(\mathrm{C} \equiv \mathrm{CPh})(\mathrm{PP}) \mathrm{Cp}^{\prime}$ described above, referenced against the ferrocene/ferrocenium couple. Given the contribution from the aryl ring to the redox-active orbital in these systems, it is unsurprising that perfluorination of the arylalkynyl ligand leads to less thermodynamically favourable oxidation (e.g., $2+0.10 \mathrm{~V}, 3-0.04 \mathrm{~V}$ ) than found in the hydrocarbon analogues such as $\mathrm{Ru}(\mathrm{C} \equiv \mathrm{CPh})($ dppe $) \mathrm{Cp}(-0.08 \mathrm{~V})$ and $\mathrm{Ru}(\mathrm{C} \equiv \mathrm{CPh})(\mathrm{dppe}) \mathrm{Cp}^{*}(-0.26 \mathrm{~V}) .{ }^{9,31,32}$ The fluorinated bimetallic complexes 8-10 and the hydrocarbon analogues 11-13 each undergo two reversible oxidation events, $E_{1}$ and $E_{2}$ with $\Delta E_{\mathrm{p}}=$ $\left|E_{2}-E_{1}\right|$ ca. 200-300 mV. The larger $\Delta E_{\mathrm{p}}$ values are generally associated with the complexes featuring perfluorinated bridges, and indicate the greater stability of the mono-oxidised species with respect to disproportionation. This is likely a consequence of the higher thermodynamic barrier to the second oxidation brought

Table 3 Electrochemical data from 2-3, 8-13 and related systems ${ }^{a}$

\begin{tabular}{llll}
\hline Compound & $E_{1}$ & $E_{2}$ & $\Delta E_{\mathrm{p}}$ \\
\hline $\mathbf{2}$ & 0.10 & - & - \\
$\mathbf{3}$ & -0.04 & - & - \\
$\mathrm{Ru}(\mathrm{C} \equiv \mathrm{CPh})\left(\mathrm{PPh}_{3}\right)_{2} \mathrm{Cp}^{b}$ & 0.11 & - & - \\
$\mathrm{Ru}(\mathrm{C} \equiv \mathrm{CPh})(\mathrm{dppe}) \mathrm{Cp}$ & -0.08 & - & - \\
$\mathrm{Ru}(\mathrm{C} \equiv \mathrm{CPh})(\mathrm{dppe}) \mathrm{Cp} \mathrm{p}^{*}$ & -0.26 & - & - \\
$\mathbf{8}$ & -0.09 & 0.21 & 0.30 \\
$\mathbf{9}$ & -0.17 & 0.11 & 0.28 \\
$\mathbf{1 0}$ & -0.35 & -0.03 & 0.32 \\
$\mathbf{1 1}$ & -0.30 & -0.01 & 0.29 \\
$\mathbf{1 2}$ & -0.32 & -0.09 & 0.23 \\
$\mathbf{1 3}$ & -0.50 & -0.22 & 0.28
\end{tabular}

${ }^{a} \mathrm{CH}_{2} \mathrm{Cl}_{2} / 0.1 \mathrm{M}\left[\mathrm{NBu}_{4}\right] \mathrm{BF}_{4}$, Pt microdisk working, Pt wire counter, Pt wire pseudoreference electrodes, potentials in Volts $v$. $\mathrm{FeCp}_{2} /\left[\mathrm{FeCp}_{2}\right]^{+}$, via reference to $\mathrm{FeCp}_{2}, \mathrm{FeCp}^{*}{ }_{2}$ or $\mathrm{CoCp}_{2}{ }^{+}$internal standards. ${ }^{b}$ Data from ref. 9. about by the electron-withdrawing fluoro substituents. The first oxidation potentials follow the same trends as observed for the monometallic complexes, with oxidation of the fluorinated species being less thermodynamically favourable when compared with the hydrocarbon analogues.

\section{Electronic structure calculations}

In order to more fully probe the influence of perfluorination on the electronic structure of compounds such as $\mathrm{Ru}\left(\mathrm{C} \equiv \mathrm{CC}_{6} \mathrm{X}_{5}\right)(\mathrm{PP}) \mathrm{Cp}^{\prime}$ and $1,4-\left\{\mathrm{Cp}^{\prime}(\mathrm{PP}) \mathrm{RuC} \equiv \mathrm{C}\right\}_{2} \mathrm{C}_{6} \mathrm{X}_{4}(\mathrm{X}=\mathrm{H}, \mathrm{F})$, a series of density functional theory (DFT) calculations (B3LYP/3-21G*) were carried out on the model systems $\mathrm{Ru}\left(\mathrm{C} \equiv \mathrm{CC}_{6} \mathrm{~F}_{5}\right)\left(\mathrm{PH}_{3}\right)_{2} \mathrm{Cp}$ (1F), $\mathrm{Ru}(\mathrm{C} \equiv \mathrm{CPh})\left(\mathrm{PH}_{3}\right)_{2} \mathrm{Cp}(\mathbf{1 - H}),{ }^{9} 1,4-\left\{\mathrm{Cp}\left(\mathrm{PH}_{3}\right)_{2} \mathrm{RuC} \equiv \mathrm{C}\right\}_{2} \mathrm{C}_{6} \mathrm{~F}_{4}(\mathbf{8}-$ F) and $1,4-\left\{\mathrm{Cp}\left(\mathrm{PH}_{3}\right)_{2} \mathrm{RuC} \equiv \mathrm{C}\right\}_{2} \mathrm{C}_{6} \mathrm{H}_{4}$ (11-H). Results from the structural optimisations are summarised in Table 4, with relevant data from single crystal X-ray diffraction experiments of suitable compounds for comparison. Details of the orbital energies and compositions are summarised in Tables 5 and 6 , and important orbitals are illustrated in Fig. 6-9. Whilst the basis set employed is relatively small, it has proven to be entirely satisfactory against other, larger, basis sets for $\mathrm{Ru}\left(\mathrm{C} \equiv \mathrm{CC}_{6} \mathrm{X}_{5}\right)(\mathrm{PP}) \mathrm{Cp}^{\prime}$ type compounds. ${ }^{9}$

The electronic structures of pseudo-octahedral $\mathrm{d}^{6}$ metal alkynyl complexes such as $\mathbf{1 - H}$ have been studied on previous occasions at various levels of theory, ${ }^{7-9}$ and only pertinent details are summarised here for completeness. The highest occupied molecular orbitals of the monometallic systems $\mathbf{1 - H}$ and $\mathbf{1 - F}$ essentially comprise the antibonding combinations of the orthogonal acetylene $\pi$-system with metal d-orbitals of appropriate symmetry (Fig. 6 and 7). The acetylide phenyl substituent is oriented either orthogonally (1-H) or co-planar (1-F) with a plane bisecting the $\mathrm{P}-\mathrm{Ru}-\mathrm{P}$ angle. However, the barrier to rotation around the $\mathrm{C}(2)-\mathrm{C}(21)$ bond is small (estimated at 0.3 and $0.4 \mathrm{kcal} \mathrm{mol}^{-1}$ for $\mathbf{1 - H}$ and $\mathbf{1 - F}$, respectively, at $\mathrm{B} 3 \mathrm{LYP} / 3-21 \mathrm{G}^{*}$ ) and the preferential orientation 
Table 4 Optimised structural data from 1-H, 1-F, 8-F and 11-H, with crystallographic data from related systems

\begin{tabular}{|c|c|c|c|c|c|c|c|}
\hline & $1-\mathrm{H}$ & $\mathrm{Ru}(\mathrm{C} \equiv \mathrm{CPh})\left(\mathrm{PPh}_{3}\right)_{2} \mathrm{Cp}^{a}$ & $1-F$ & 1 & 8-F & 8 & 11-H \\
\hline $\mathrm{Ru}-\mathrm{C}(1)$ & 2.018 & $2.016(3)$ & 2.001 & $1.991(6)$ & 2.005 & $1.996(2)$ & 2.018 \\
\hline $\mathrm{Ru}-\mathrm{P}$ & 2.278 & $2.285(1), 2.303(1)$ & 2.284 & $2.295(2), 2.282(2)$ & 2.282 & $2.2542(7), 2.2607(7)$ & 2.277 \\
\hline$C(2)-C(21)$ & 1.426 & $1.456(4)$ & 1.406 & $1.421(9)$ & 1.407 & $1.427(3)$ & 1.423 \\
\hline$\theta^{b}$ & - & - & - & - & 180.0 & 180 & 158.9 \\
\hline
\end{tabular}

Table 5 The energy $(E / \mathrm{eV})$ and composition of selected frontier molecular orbitals in $\mathbf{1 - F}$ and $\mathbf{1 - H}$

\begin{tabular}{|c|c|c|c|c|c|c|c|c|c|}
\hline 1-F & MO & & $E$ & $\mathrm{Cp}$ & $\mathrm{PH}_{3}$ & $\mathrm{Ru}$ & $\mathrm{C}_{\alpha}$ & $\mathrm{C}_{\beta}$ & $\mathrm{C}_{6} \mathrm{~F}_{5}$ \\
\hline & 109 & $\mathrm{~L}+4$ & -0.02 & 0 & 0 & 0 & 0 & 0 & 100 \\
\hline & 108 & $\mathrm{~L}+3$ & -0.19 & 3 & 21 & 76 & 0 & 0 & 0 \\
\hline & 107 & $L+2$ & -0.43 & 17 & 14 & 59 & 8 & 1 & 1 \\
\hline & 106 & $\mathrm{~L}+1$ & -0.66 & 2 & 2 & 4 & 15 & 1 & 76 \\
\hline & 105 & LUMO & -1.05 & 24 & 27 & 49 & 0 & 0 & 0 \\
\hline & 104 & HOMO & -5.18 & 7 & 3 & 34 & 10 & 23 & 23 \\
\hline & 103 & $\mathrm{H}-1$ & -5.68 & 8 & 5 & 60 & 6 & 19 & 1 \\
\hline & 102 & $\mathrm{H}-2$ & -6.20 & 22 & 11 & 43 & 10 & 14 & 1 \\
\hline \multirow[t]{9}{*}{ 1-H } & MO & & $E$ & $\mathrm{Cp}$ & $\mathrm{PH}_{3}$ & $\mathrm{Ru}$ & $\mathrm{C}_{\alpha}$ & $\mathrm{C}_{\beta}$ & $\mathrm{C}_{6} \mathrm{H}_{5}$ \\
\hline & 89 & $\mathrm{~L}+4$ & 0.57 & 0 & 2 & 6 & 0 & 0 & 92 \\
\hline & 88 & $\mathrm{~L}+3$ & 0.09 & 2 & 12 & 27 & 10 & 1 & 48 \\
\hline & 87 & $\mathrm{~L}+2$ & -0.03 & 3 & 11 & 54 & 6 & 2 & 26 \\
\hline & 86 & $L+1$ & -0.15 & 16 & 13 & 62 & 8 & 0 & 0 \\
\hline & 85 & LUMO & -0.78 & 24 & 27 & 50 & 0 & 0 & 0 \\
\hline & 84 & HOMO & -4.91 & 2 & 1 & 30 & 16 & 22 & 29 \\
\hline & 83 & $\mathrm{H}-1$ & -5.09 & 8 & 4 & 46 & 10 & 28 & 4 \\
\hline & 82 & $\mathrm{H}-2$ & -5.72 & 26 & 14 & 46 & 6 & 1 & 6 \\
\hline
\end{tabular}

seems to depend more upon the level of theory employed or the starting point for the geometry optimisation than any significant electronic factor. In either case, the repulsive interactions between the filled $\mathrm{M}-\mathrm{C} \equiv \mathrm{C}$ and phenyl fragment orbitals destabilise the more delocalised orbital, and therefore it is this that comprises the HOMO. The contribution from the arylalkynyl fragment to the HOMO is not negligible ( $c a .56-67 \%),{ }^{9}$ with fluorination of the

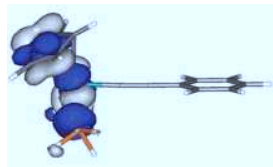

LUMO $-0.78 \mathrm{eV}$

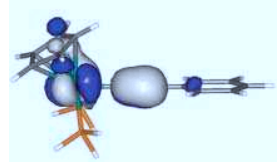

HOMO-1 $-5.09 \mathrm{eV}$

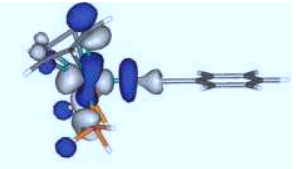

LUMO+1 $-0.15 \mathrm{eV}$

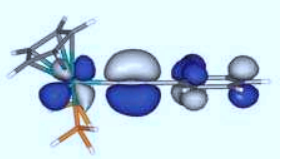

$\mathrm{HOMO}$

$-4.91 \mathrm{eV}$
Fig. 6 Frontier orbitals of $\mathbf{1 - H}$. Contour values are plotted at \pm 0.04 $\left.(\mathrm{e} \mathrm{bohr})^{-3}\right)^{1 / 2}$.

ligand resulting in only a small decrease in the ligand character. Thus, for either system descriptions of the redox chemistry in terms of metal-localised behaviour is likely an oversimplification. In contrast to the delocalised nature of the HOMO, in both 1-H and 1-F the LUMO is centred on the metal fragment, without any significant contribution from the arylalkynyl moiety (Fig. 6 and 7). The aryl/alkynyl $\pi^{*}$ systems lie above these empty metal orbitals, and, as would be expected, the $\pi^{*}$-system of the fluorinated ring is somewhat lower in energy than that of the analogous orbital from the aromatic hydrocarbon (Table 6).

Table 6 The energy $(E / \mathrm{eV})$ and composition of selected frontier molecular orbitals in 8-F and 11-H

\begin{tabular}{|c|c|c|c|c|c|c|c|c|c|c|c|c|c|c|}
\hline 8-F & MO & & $E$ & $\mathrm{Cp}(1)$ & $\mathrm{PH}_{3}(1)$ & $\mathrm{Ru}(1)$ & $\mathrm{C}_{\alpha}(1)$ & $\mathrm{C}_{\beta}(1)$ & $\mathrm{C}_{6} \mathrm{~F}_{4}$ & $\mathrm{C}_{\beta}(2)$ & $\mathrm{C}_{\alpha}(2)$ & $\mathrm{Ru}(2)$ & $\mathrm{PH}_{3}(2)$ & $\mathrm{Cp}(2)$ \\
\hline & 168 & $\mathrm{~L}+4$ & -0.16 & 9 & 7 & 30 & 4 & 0 & 0 & 0 & 4 & 29 & 7 & 9 \\
\hline & 167 & $\mathrm{~L}+3$ & -0.17 & 8 & 7 & 29 & 4 & 1 & 1 & 1 & 4 & 30 & 7 & 9 \\
\hline & 166 & $\mathrm{~L}+2$ & -0.48 & 1 & 1 & 3 & 12 & 1 & 63 & 1 & 12 & 3 & 1 & 1 \\
\hline & 165 & $\mathrm{~L}+1$ & -0.79 & 24 & 27 & 49 & 0 & 0 & 0 & 0 & 0 & 0 & 0 & 0 \\
\hline & 164 & LUMO & -0.79 & 0 & 0 & 0 & 0 & 0 & 0 & 0 & 0 & 49 & 27 & 24 \\
\hline & 163 & HOMO & -4.49 & 3 & 1 & 14 & 9 & 11 & 25 & 11 & 9 & 14 & 1 & 3 \\
\hline & 162 & H-1 & -5.33 & 5 & 2 & 24 & 2 & 12 & 10 & 12 & 2 & 24 & 2 & 5 \\
\hline & 161 & $\mathrm{H}-2$ & -5.37 & 3 & 2 & 30 & 4 & 11 & 2 & 10 & 4 & 28 & 2 & 3 \\
\hline \multirow[t]{9}{*}{ 11-H } & MO & & $E$ & $\mathrm{Cp}(1)$ & $\mathrm{PH}_{3}(1)$ & $\operatorname{Ru}(1)$ & $\mathrm{C}_{\alpha}(1)$ & $\mathrm{C}_{\beta}(1)$ & $\mathrm{C}_{6} \mathrm{H}_{4}$ & $\mathrm{C}_{\beta}(2)$ & $\mathrm{C}_{\alpha}(2)$ & $\mathrm{Ru}(2)$ & $\mathrm{PH}_{3}(2)$ & $\mathrm{Cp}(2)$ \\
\hline & 152 & $\mathrm{~L}+4$ & -0.02 & 1 & 2 & 4 & 11 & 2 & 59 & 2 & 11 & 4 & 2 & 1 \\
\hline & 151 & $\mathrm{~L}+3$ & -0.03 & 9 & 7 & 36 & 4 & 0 & 0 & 0 & 4 & 28 & 6 & 7 \\
\hline & 150 & $\mathrm{~L}+2$ & -0.04 & 7 & 5 & 28 & 3 & 0 & 0 & 0 & 4 & 36 & 7 & 9 \\
\hline & 149 & $\mathrm{~L}+1$ & -0.66 & 0 & 0 & 0 & 0 & 0 & 0 & 0 & 0 & 50 & 27 & 24 \\
\hline & 148 & LUMO & -0.67 & 24 & 27 & 50 & 0 & 0 & 0 & 0 & 0 & 0 & 0 & 0 \\
\hline & 147 & HOMO & -4.17 & 2 & 1 & 12 & 11 & 9 & 30 & 9 & 11 & 12 & 1 & 2 \\
\hline & 146 & H-1 & -5.11 & 5 & 2 & 23 & 3 & 13 & 8 & 13 & 3 & 23 & 2 & 5 \\
\hline & 145 & $\mathrm{H}-2$ & -5.14 & 2 & 2 & 30 & 6 & 14 & 2 & 11 & 5 & 23 & 1 & 2 \\
\hline
\end{tabular}




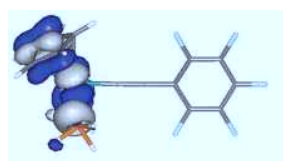

LUMO

$-1.05 \mathrm{eV}$

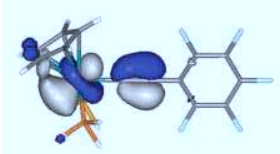

HOMO-1

$-5.68 \mathrm{eV}$

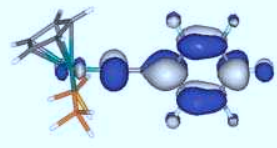

$\mathrm{LUMO}+1$

$-0.66 \mathrm{eV}$

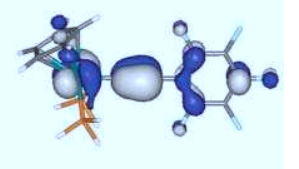

HOMO
Fig. 7 Frontier orbitals of 1-F. Contour values are plotted at \pm 0.04 $\left.(\mathrm{e} \mathrm{bohr})^{-3}\right)^{1 / 2}$.

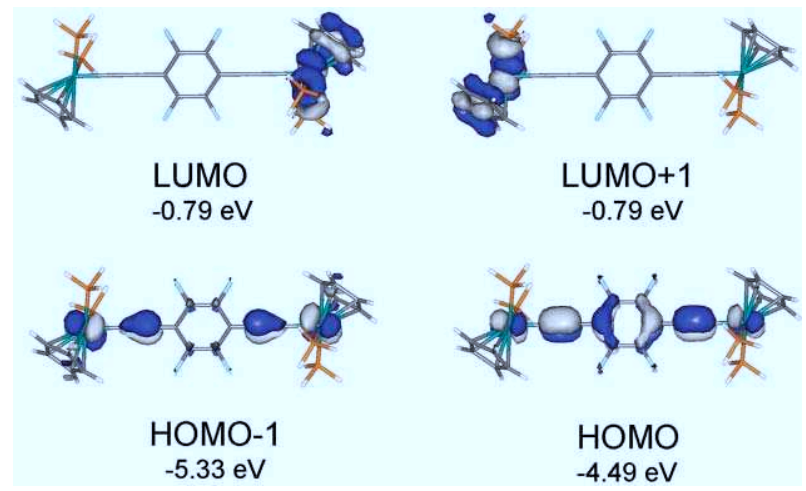

Fig. 8 Frontier orbitals of 8-F. Contour values are plotted at \pm 0.04 $\left(\mathrm{e} \mathrm{bohr} \mathrm{r}^{-3}\right)^{1 / 2}$.
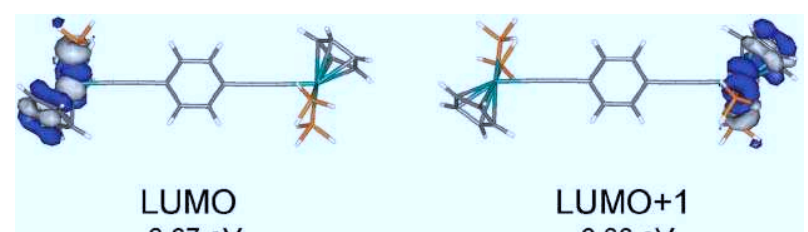

$-0.67 \mathrm{eV}$

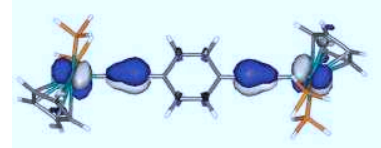

HOMO-1

$-5.11 \mathrm{eV}$

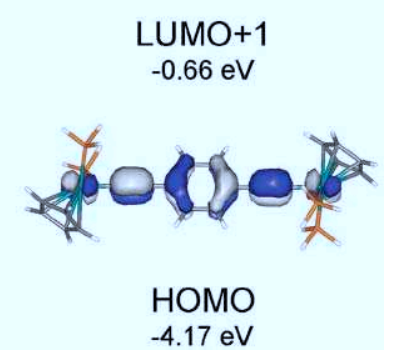

Fig. 9 Frontier orbitals of 11-H. Contour values are plotted at \pm 0.04 $\left(\mathrm{e} \mathrm{bohr} \mathrm{r}^{-3}\right)^{1 / 2}$.

In general, perfluorination has little effect on the gross description of the electronic structure of the arylalkynyl complexes of ruthenium described here, save to stabilise the orbital manifold to some extent. A small elongation of the calculated $\mathrm{Ru}-\mathrm{P}$ bond lengths is not reproduced within the level of precision of the structure determinations of $\mathrm{Ru}(\mathrm{C} \equiv \mathrm{CPh})\left(\mathrm{PPh}_{3}\right)_{2} \mathrm{Cp}^{23}$ and $\mathbf{1}$. However, the contraction of the $\mathrm{Ru}-\mathrm{C}(1)$ bond length observed upon comparison of the optimised geometries of $\mathbf{1 - H}$ and $\mathbf{1 - F}$ is reflected at the limit of precision in the experimentally determined structures, and likely arises from the greater electrostatic attraction of the $\mathrm{Ru}$ and $\mathrm{C}(1)$ centres in the case of the fluorinated compound.
The calculated electronic structures of the bimetallic systems 11-H and 8-F, which are similar to each other, merit consideration and discussion. Geometry optimisations for 11-H and 8-F show minima (type $\mathbf{A}$ ) with the phenyl ring of the bridging ligand orthogonal to the plane bisecting the $\mathrm{P}-\mathrm{Ru}-\mathrm{P}$ angles and minima (type B) with the phenyl ring of the bridging ligand co-planar with the plane bisecting the $\mathrm{P}-\mathrm{Ru}-\mathrm{P}$ angle. Both minima $\mathbf{A}$ and $\mathbf{B}$ have the same energies at B3LYP/3-21G* for 11-H and 8-F. Similar behaviour for related systems has been noted elsewhere. ${ }^{33}$ Here we focus on type A minima in detail for 11-H and 8-F, although similar conclusions for structure type $\mathbf{B}$ may also be made.

The HOMOs of 11-H and 8-F are, in each case, of comparable composition to those of the mononuclear models (Fig. 8 and 9), being delocalised over the metal centres, alkynyl fragment and aromatic ring system. Interestingly, the HOMO in 11-H and 8-F is $65-70 \%$ diethynyl aromatic ligand in character, and consequently the compounds are best described in terms of an organic diethynylarylene featuring strong $\pi$-donating substituents [the $\mathrm{Ru}(\mathrm{PP}) \mathrm{Cp}^{\prime}$ fragments]. In each case, the HOMO is wellseparated in energy from the other occupied orbitals, in agreement with the electrochemical observation of two anodic events. The HOMO-1 can be described in terms of the various other inand out-of-phase combinations of the metal (d) and acetylide $(\pi)$ orbitals, and being lower in energy in the case of the fluorinated derivative (Fig. 8 and 9, Table 6). Within the unoccupied orbital manifold the diethynylbenzene $\pi^{*}$ system is interleaved within the unoccupied metal $d$ orbitals, with the fluorinated system naturally lying lower in energy than the hydrocarbon analogue (Table 6). Interestingly, although Koopmans' theorem has no direct correlation with DFT-based methods of electronic structure calculation, the HOMO in $\mathbf{1 1 - H}$ is higher in energy than the HOMO in 8-F. This energy order maps with the differences in redox properties of $\mathbf{1 1}$ and $\mathbf{8}$, and supports the fairly intuitive observation than the introduction of the perfluoroaryl group leads to less thermodynamically favourable oxidation processes (vide supra).

\section{UV-Vis-NIR spectroelectrochemistry}

To provide an experimental check of the key conclusions drawn from the computational work (i.e. that the electronic structures of the bimetallic ruthenium complexes $1,4-\left\{\mathrm{Cp}^{\prime}(\mathrm{PP}) \mathrm{RuC} \equiv \mathrm{C}\right\}_{2} \mathrm{C}_{6} \mathrm{X}_{4}$ $(\mathrm{X}=\mathrm{H}, \mathrm{F})$ are largely insensitive to fluorination of the alkynylaryl ring system, and that the HOMOs contain a very large amount of alkynylaryl character), UV-Vis-NIR spectroelectrochemical studies were conducted on complexes 10 and 13 (Fig. 10), chosen as samples representative of the series 8-13. The spectra of the neutral complexes $\mathbf{1 0}$ and $\mathbf{1 3}$ are similar, each being dominated by an intense band at $27100(\mathbf{1 3})$ or $24900(\mathbf{1 0}) \mathrm{cm}^{-1}$. The red-shift of this band on fluorination of the phenylene ring is consistent with the assignment of the band to an MLCT transition, or perhaps more accurately to a bridge-based $\pi-\pi^{*}$ transition, albeit with the $\pi$-orbitals of the bridge admixed with some metal character (ML-LCT). In each case, this characteristic band collapses upon one-electron oxidation and is replaced by structured bands or composite band envelopes in the region $20000-17000 \mathrm{~cm}^{-1}$ and $8000-5000 \mathrm{~cm}^{-1}$.

Both $[\mathbf{1 0}]^{+}$and $[\mathbf{1 3}]^{+}$feature structured bands in the visible region that are similar to those observed in related radical 

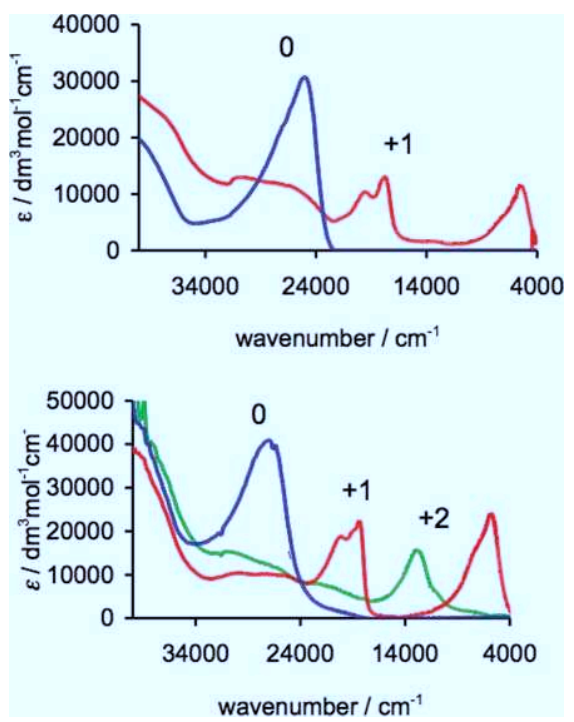

Fig. 10 The UV-Vis-NIR spectra of $[\mathbf{1 0}]^{n+}$ (top) and $[\mathbf{1 3}]^{n+}$ (bottom) $\left(\mathrm{CH}_{2} \mathrm{Cl}_{2} / 0.1 \mathrm{M} \mathrm{NBu} \mathrm{BF}_{4}\right)$.

complexes $^{34}$ and compounds ${ }^{35}$ in which the phenylene ring systems are intimately involved in supporting the unpaired electron. When this experimental observation is considered alongside the DFT results, it is reasonable to describe oxidation of the ruthenium complexes 1,4- $\left\{\mathrm{Cp}^{\prime}(\mathrm{PP}) \mathrm{RuC} \equiv \mathrm{C}\right\}_{2} \mathrm{C}_{6} \mathrm{X}_{4}$ in terms of depopulation of the HOMO to give a SOMO of comparable character to those depicted in Fig. 8 and 9. The band envelope in the NIR region is similar in each of $[\mathbf{1 0}]^{+}$and $[\mathbf{1 3}]^{+}$, and can be deconvoluted into the sum of two Gaussian-shaped components (Fig. 11), which contrasts with more complex deconvolutions associated with the NIR spectrum of the strongly coupled mixed valence complex $1,4-\left[\left\{\mathrm{Cp}^{*}(\mathrm{dppe}) \mathrm{FeC} \equiv \mathrm{C}\right\}_{2} \mathrm{C}_{6} \mathrm{H}_{4}\right]^{+}$due to the pronounced "cut-off" on the high energy side, and potential complications arising from multiple IVCT transitions. ${ }^{36}$ The almost identical band-shapes of
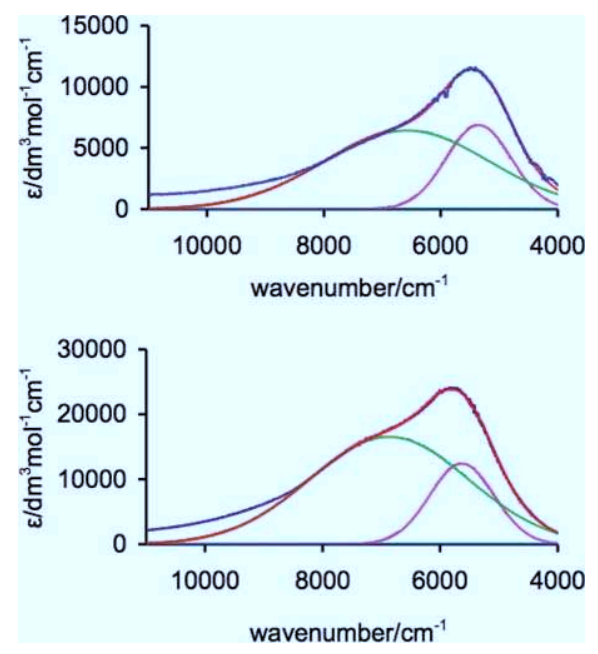

Fig. 11 The NIR region of $[\mathbf{1 0}]^{+}$(top) and $[\mathbf{1 3}]^{+}$(bottom) showing the deconvolution of the absorption envelope into a sum of two Gaussian shaped components $\left([\mathbf{1 0}]^{+}: \bar{v}_{\max }=5352 \mathrm{~cm}^{-1}, \Delta \bar{v} \frac{1}{2}=1114 \mathrm{~cm}^{-1}\right.$, $\varepsilon=6875 \mathrm{dm}^{3} \mathrm{~mol}^{-1} \mathrm{~cm}^{-1} ; \bar{v}_{\max }=6584 \mathrm{~cm}^{-1}, \Delta \bar{v} \frac{1}{2}=2834 \mathrm{~cm}^{-1}, \varepsilon=$ $6432 \mathrm{dm}^{3} \mathrm{~mol}^{-1} \mathrm{~cm}^{-1} \cdot[13]^{+} \bar{v}_{\max }=5630 \mathrm{~cm}^{-1}, \Delta \bar{v} \frac{1}{2}=1102 \mathrm{~cm}^{-1}, \varepsilon=$ $12410 \mathrm{dm}^{3} \mathrm{~mol}^{-1} \mathrm{~cm}^{-1} ; \bar{v}_{\max }=6874 \mathrm{~cm}^{-1}, \Delta \bar{v} \frac{1}{2}=2700 \mathrm{~cm}^{-1}, \varepsilon=$ $\left.16553 \mathrm{dm}^{3} \mathrm{~mol}^{-1} \mathrm{~cm}^{-1}\right)$. the components in the NIR band envelopes of $[\mathbf{1 0}]^{+}$and $[\mathbf{1 3}]^{+}$ provides yet more evidence for the electronic similarity of these compounds. The absorption profile is red-shifted in the case of the fluorinated ring system, consistent with transfer of electron density to the phenylene-based orbitals in the transitions responsible for these bands, providing further evidence for the involvement of the phenylene ring in the redox active orbital. The deconvoluted NIR bands are also considerably narrower than predicted from the Hush model for weakly-coupled mixed-valence compounds, ${ }^{37}$ and too intense to be simple dd bands associated with a $\mathrm{d}^{5}$ metal centre. Therefore, the lower energy component is assigned to the [HOMO-1] to SOMO transition, which has metal-ethynyl (d- $\pi$ ) to $\operatorname{aryl}(\pi)$ character. The higher energy component can be attributed to a transition from a lower-lying, more metal based orbital (or orbitals) to the SOMO (i.e. an M-MLCT transition).

Although an electrogenerated sample of the dication $[\mathbf{1 0}]^{2+}$ decomposed before a reliable spectrum could be obtained, the UVVis-NIR spectrum of the dication $[\mathbf{1 3}]^{2+}$ was satisfactorily obtained by controlled potential electrolysis in a spectroelectrochemical cell, as evidenced by the sequential re-reduction through $[\mathbf{1 3}]^{+}$ to [13]. The spectrum of [13 $]^{2+}$ (Fig. 10) is similar in profile to that of $\left[\mathrm{Ru}\left(\mathrm{C} \equiv \mathrm{CC}_{6} \mathrm{H}_{4} \mathrm{Me}-4\right)(\mathrm{dppe}) \mathrm{Cp}^{*}\right]^{+}$, and by analogy the major visible band in $[\mathbf{1 3}]^{2+}$ can be assigned to a metal-to-metal/ligand (M-MLCT) transition. ${ }^{9}$ A weaker band is also present in the NIR region of $[\mathbf{1 3}]^{2+}$, which is similar to that observed for the analogous mononuclear system $[3]^{+}$and may therefore be assigned to a similar transition between approximately orthogonal orbitals with significant metal d/ethynyl $\pi$ character. ${ }^{9}$

Taken as a whole, these UV-Vis-NIR spectroscopic data support the conclusions drawn from the DFT work, and indicate that the frontier/redox active orbitals in 1,4- $\left\{\mathrm{Cp}^{\prime}(\mathrm{PP}) \mathrm{RuC} \equiv \mathrm{C}\right\}_{2} \mathrm{C}_{6} \mathrm{X}_{4}$ systems are heavily centred on the bridging ligand. It is therefore not appropriate to discuss the properties of these compounds in terms of mixed-valence models, but rather they should be regarded as further examples of bimetallic compounds featuring redox "non-innocent" bridging ligands. ${ }^{38}$

\section{Conclusions}

This work has demonstrated the efficient syntheses of several complexes featuring mono- and di-ethynyl derivatives of perfluoroinated phenyl and phenylene ring systems, by treating the readily available $\mathrm{SiMe}_{3}$-protected alkyne with equivalent amounts of the metal-halide precursor either in a fluoride- or $\mathrm{NaOMe-initiated}$ desilylation/metallation reaction sequence. Whilst nucleophilic substitution reactions are common in the chemistry of perfluoroaromatics, the introduction of a strong inductive electrondonating metal alkynyl fragment effectively turns off this reaction pathway. Gold-modified Sonogashira and Cadiot-Chodkiewicz coupling protocols are also effective as chain extension reactions involving perfluorophenyl rings. In the case of the monometallic (1-3) and bimetallic (8-13) ruthenium alkynyl complexes, perfluorination of the alkynyl-based ligand does not greatly affect the overall electronic structure of the compounds. Rather, perfluorination leads to a small stabilisation of the orbital manifold, and consequently less thermodynamically favourable oxidation. Interestingly, calculations reveal a significant (ca. 60-70\%) contribution from the ethynyl aromatic moiety to the HOMOs in the ruthenium systems. This prediction is supported by 
UV-Vis-NIR spectroscopy, and raises questions about the nature of the oxidation events (metal- $v$ s. ligand- centred) and "mixed valence" character of many similar ruthenium/alkynyl based systems. Further experiments directed at probing this point are in progress and will be reported elsewhere.

\section{Experimental}

\section{General}

All reactions were carried out under dry nitrogen, although normally no special precautions to exclude air were taken during subsequent work-up. Common solvents were dried, distilled under nitrogen and degassed before use. Separations were carried out by preparative thin-layer chromatography on glass plates $(20 \times$ $20 \mathrm{~cm}^{2}$ ) coated with silica gel (Merck, $0.5 \mathrm{~mm}$ thick).

\section{Instruments}

IR spectra were obtained on a Bruker IFS28 FT-IR spectrometer from samples mounted between $\mathrm{NaCl}$ windows. NMR spectra were recorded on a Varian 2000 instrument $\left({ }^{1} \mathrm{H}\right.$ at $300.13 \mathrm{MHz}$, ${ }^{13} \mathrm{C}$ at $75.47 \mathrm{MHz},{ }^{31} \mathrm{P}$ at $121.503,{ }^{19} \mathrm{~F}$ at $282.39 \mathrm{MHz}$ ). Unless otherwise stated, samples were dissolved in $\mathrm{CDCl}_{3}$ or $\mathrm{C}_{6} \mathrm{D}_{6}$ contained in $5 \mathrm{~mm}$ sample tubes. Chemical shifts are given in ppm relative to internal $\mathrm{SiMe}_{4}$ for ${ }^{1} \mathrm{H}$ and ${ }^{13} \mathrm{C}$ NMR spectra and external $\mathrm{H}_{3} \mathrm{PO}_{4}$ for ${ }^{31} \mathrm{P}$ NMR spectra. ${ }^{19} \mathrm{~F}$ NMR spectra were referenced to $\mathrm{CFCl}_{3}$, with internal $\mathrm{C}_{6} \mathrm{~F}_{6}\left(\delta_{\mathrm{F}}-164.9\right)$ as the standard. Electrospray mass spectra (ES-MS) were obtained from samples dissolved in $\mathrm{MeOH}$ unless otherwise indicated. Solutions were injected into a Fisons VG Platform II spectrometer via a $10 \mathrm{ml}$ injection loop. Nitrogen was used as the drying and nebulising gas. $\mathrm{NaOMe}$ was used as an aid to ionisation when required ${ }^{39}$ Peaks listed are the highest intensity ions in the isotopic envelopes. Electrochemical samples $(1 \mathrm{mM})$ were dissolved in $\mathrm{CH}_{2} \mathrm{Cl}_{2}$ containing $0.1 \mathrm{M}\left[\mathrm{NBu}_{4}\right] \mathrm{BF}_{4}$ as the supporting electrolyte. Cyclic voltammograms were recorded using a PAR Model 263 potentiostat and a cell with all $\mathrm{Pt}$ electrodes, and reported against ferrocene $\left(\mathrm{FeCp}_{2} /\left[\mathrm{FeCp}_{2}\right]^{+}=+0.00 \mathrm{~V}\right)$. Under these conditions, the decamethylferrocene/decamethylferrocenium couple is $-0.53 \mathrm{~V}$, and cobaltocene/cobaltocenium $-1.34 \mathrm{~V}$. Elemental analyses were by CMAS, Belmont, Vic., Australia. Details of the spectroelectrochemical cell and conditions have been published elsewhere. ${ }^{9}$

\section{Reagents}

The compounds $\mathrm{RuCl}(\mathrm{dppe}) \mathrm{Cp} *{ }^{*}{ }^{10 d} \mathrm{Me}_{3} \mathrm{SiC} \equiv \mathrm{CC}_{6} \mathrm{~F}_{5},{ }^{16} 1,4-\left(\mathrm{Me}_{3}-\right.$ $\mathrm{SiC} \equiv \mathrm{C})_{2} \mathrm{C}_{6} \mathrm{~F}_{4},{ }^{16 a, 22} \quad \mathrm{Pt}_{2}(\mu-\mathrm{dppm})_{2} \mathrm{Cl}_{2},{ }^{19} \mathrm{Ru}\left(\mathrm{C} \equiv \mathrm{CC}_{6} \mathrm{~F}_{5}\right)\left(\mathrm{PPh}_{3}\right)_{2} \mathrm{Cp},{ }^{5}$ $1,4-\left\{\mathrm{Cp}\left(\mathrm{PPh}_{3}\right)_{2} \mathrm{Ru}(\mathrm{C} \equiv \mathrm{C})\right\}_{2} \mathrm{C}_{6} \mathrm{H}_{4} \quad(\mathbf{1 1}){ }^{40} \mathrm{RuCl}(\mathrm{dppe}) \mathrm{Cp},{ }^{41} \mathrm{RuCl}-$ $\left(\mathrm{PPh}_{3}\right)_{2} \mathrm{Cp},{ }^{42} \mathrm{Mo}(\equiv \mathrm{CBr})(\mathrm{CO})_{2} \mathrm{Tp}^{*},{ }^{43} \mathrm{Pd}\left(\mathrm{PPh}_{3}\right)_{4},{ }^{44} \mathrm{Co}_{3}\left(\mu_{3}-\mathrm{CBr}\right)(\mu-$ dppm $)(\mathrm{CO})_{7},{ }^{30 a} \quad \mathrm{IC} \equiv \mathrm{CFc}{ }^{45} \quad \mathrm{Au}\left(\mathrm{C} \equiv \mathrm{CC}_{6} \mathrm{~F}_{5}\right)\left(\mathrm{PPh}_{3}\right)^{46}$ and $\mathrm{Ru}(\mathrm{C} \equiv$ $\mathrm{CPh})(\mathrm{dppe}) \mathrm{Cp}^{\prime}\left(\mathrm{Cp}^{\prime}=\mathrm{Cp}, \mathrm{Cp}^{*}\right)^{31}$ were all prepared as described previously.

\section{$\operatorname{Ru}\left(\mathrm{C} \equiv \mathrm{CC}_{6} \mathrm{~F}_{5}\right)\left(\mathrm{PPh}_{3}\right)_{2} \mathrm{Cp}(1)$}

A sample of this complex was obtained as previously described, ${ }^{5}$ and recrystallised from dichloromethane/hexanes for the crystallographic study.

\section{Derivatives of $\mathrm{Me}_{3} \mathrm{SiC} \equiv \mathrm{CC}_{6} \mathrm{~F}_{5}$}

(a) $\mathbf{R u}\left(\mathbf{C} \equiv \mathbf{C C}_{6} \mathbf{F}_{5}\right)$ (dppe)Cp (2). A mixture of $\mathrm{Me}_{3} \mathrm{SiC} \equiv \mathrm{CC}_{6} \mathrm{~F}_{5}$ (300 mg, $1.13 \mathrm{mmol}$ ), RuCl(dppe)Cp (456 mg, $0.76 \mathrm{mmol}$ ) and $\mathrm{KF}$ (44 mg, $0.15 \mathrm{mmol}$ ) in $\mathrm{MeOH}(20 \mathrm{ml})$ was heated under reflux for $5 \mathrm{~h}$. The resulting yellow precipitate was collected and washed with $\mathrm{MeOH}$ followed by hexane to give $\mathrm{Ru}\left(\mathrm{C} \equiv \mathrm{CC}_{6} \mathrm{~F}_{5}\right)(\mathrm{dppe}) \mathrm{Cp}$ (2) $(575 \mathrm{mg}, 63 \%)$. Anal. Calcd $\left(\mathrm{C}_{39} \mathrm{H}_{29} \mathrm{~F}_{5} \mathrm{P}_{2} \mathrm{Ru}\right)$ : C, 61.99; H, 3.87; $M$, 755. Found: C, 61.93; H, 3.83. IR (Nujol, $\left.\mathrm{cm}^{-1}\right): v(\mathrm{CC}) 2097$ m, 2070 w. ${ }^{1} \mathrm{H}$ NMR $\left(\mathrm{C}_{6} \mathrm{D}_{6}\right): \delta 2.16,2.71\left(2 \mathrm{~m}, 2 \times 2 \mathrm{H}, \mathrm{CH}_{2} \mathrm{CH}_{2}\right)$, 4.73 (s, 5H, Cp), 6.95-7.99 (m, 24H, Ph). ${ }^{13} \mathrm{C}$ NMR: $\delta 27.8[\mathrm{t}$, $J(\mathrm{CP}) 23 \mathrm{~Hz}, \mathrm{CH}_{2} \mathrm{CH}_{2}$ ], 83.0 (s, Cp), 126.1-142.5 (m, Ph). ${ }^{19} \mathrm{~F}$ NMR: $\delta-145.6(\mathrm{~m}, 2 \mathrm{~F}, o-\mathrm{F}),-168.3[\mathrm{t}, J(\mathrm{FF})=21 \mathrm{~Hz}, 1 \mathrm{~F}, p-\mathrm{F}]$, -168.8 (m, 2F, $m-\mathrm{F}) .{ }^{31} \mathrm{P}$ NMR: $\delta 87.0$ (s, dppe). ES-MS (MeOH + $\mathrm{NaOMe}, m / z)$ : 779, $[\mathrm{M}+\mathrm{Na}]^{+} ; 756,[\mathrm{M}+\mathrm{H}]^{+} ; 738,[\mathrm{M}-\mathrm{F}]^{+} ; 593$, $[\mathrm{Ru}(\mathrm{CO})(\mathrm{dppe}) \mathrm{Cp}]^{+} ; 565,[\mathrm{Ru}(\mathrm{dppe}) \mathrm{Cp}]^{+}$.

(b) $\mathbf{R u}\left(\mathbf{C} \equiv \mathbf{C C}_{6} \mathbf{F}_{5}\right)(\mathbf{d p p e}) \mathbf{C p} *(3)$. In a procedure similar to that used for $2, \mathrm{Me}_{3} \mathrm{SiC} \equiv \mathrm{CC}_{6} \mathrm{~F}_{5}$ (200 mg, $0.76 \mathrm{mmol}$ ), $\mathrm{RuCl}(\mathrm{dppe}) \mathrm{Cp}^{*}$ (508 mg, $0.76 \mathrm{mmol})$ and $\mathrm{KF}(44 \mathrm{mg}, 0.76 \mathrm{mmol})$ and $\mathrm{MeOH}$ $(20 \mathrm{ml})$ gave a pale green precipitate of $\mathrm{Ru}\left(\mathrm{C} \equiv \mathrm{CC}_{6} \mathrm{~F}_{5}\right)(\mathrm{dppe}) \mathrm{Cp}^{*}$ (3) (339 mg, 54\%). Anal. Calcd $\left(\mathrm{C}_{44} \mathrm{H}_{39} \mathrm{~F}_{5} \mathrm{P}_{2} \mathrm{Ru}\right)$ : C, 64.00; H, 4.76; $M, 826$. Found: C, 63.98; H, 4.80. IR (Nujol, $\mathrm{cm}^{-1}$ ): $v(\mathrm{CC}) 2078$ $\mathrm{m}, 2033 \mathrm{s.}{ }^{1} \mathrm{H}$ NMR $\left(\mathrm{C}_{6} \mathrm{D}_{6}\right): \delta 1.66\left(\mathrm{~s}, 15 \mathrm{H}, \mathrm{Cp}^{*}\right), 2.01,2.81(2 \mathrm{~m}$, $\left.2 \times 2 \mathrm{H}, \mathrm{CH}_{2} \mathrm{CH}_{2}\right), 7.02-7.87(\mathrm{~m}, 20 \mathrm{H}, \mathrm{Ph}) .{ }^{13} \mathrm{C}$ NMR: $\delta 10.6(\mathrm{~s}$, $\left.\mathrm{C}_{5} M_{5}\right), 29.9\left[\mathrm{t}, J(\mathrm{CP})=23 \mathrm{~Hz}, \mathrm{CH}_{2} \mathrm{CH}_{2}\right], 92.7(\mathrm{~s}, \mathrm{C} \equiv \mathrm{C}), 93.84$ (s, $\left.C_{5} \mathrm{Me}_{5}\right), 127.1-144.7(\mathrm{~m}, \mathrm{Ph}) .{ }^{19} \mathrm{~F}$ NMR: $\delta-169.1[\mathrm{t}, J(\mathrm{FF})=$ $21 \mathrm{~Hz}, 1 \mathrm{~F}, p-\mathrm{F}],-168.9$ (m, 2F, $p-\mathrm{F}),-145.8$ (m, 2F, $o-\mathrm{F}) .{ }^{31} \mathrm{P}$ NMR: $\delta 81.7$ (s, dppe). ES-MS (MeOH $+\mathrm{NaOMe}, \mathrm{m} / z): 848,[\mathrm{M}+\mathrm{Na}]^{+}$; 827, $[\mathrm{M}+\mathrm{H}]^{+} ; 808,\left[\mathrm{M}-\mathrm{F}^{+} ; 662,\left[\mathrm{Ru}(\mathrm{CO})(\mathrm{dppe}) \mathrm{Cp}^{*}\right]^{+} ; 635\right.$, $\left[\mathrm{Ru}(\mathrm{dppe}) \mathrm{Cp}^{*}\right]^{+}$.

(c) $\mathbf{P t}_{2}(\boldsymbol{\mu} \text {-dppm })_{2}\left(\mathbf{C} \equiv \mathrm{CC}_{6} \mathbf{F}_{5}\right)_{2}$ (4). To a stirred suspension of $\mathrm{Pt}_{2}(\mu \text {-dppm })_{2} \mathrm{Cl}_{2}(100 \mathrm{mg}, 0.08 \mathrm{mmol})$ in $\mathrm{NaOMe}$ [from $\mathrm{Na}(50 \mathrm{mg})$ in $\mathrm{MeOH}(10 \mathrm{ml})]$ was added an excess of $\mathrm{Me}_{3} \mathrm{SiC} \equiv \mathrm{CC}_{6} \mathrm{~F}_{5}(50 \mathrm{mg})$. This mixture was stirred at r.t. for $6 \mathrm{~h}$ before the resulting precipitate was collected and washed with $\mathrm{MeOH}$ followed by hexane to give $\mathrm{Pt}_{2}(\mu-\mathrm{dppm})_{2}\left(\mathrm{C} \equiv \mathrm{CC}_{6} \mathrm{~F}_{5}\right)_{2}$ (6) $(33 \mathrm{mg}, 26 \%)$. Anal. Calcd $\left(\mathrm{C}_{66} \mathrm{H}_{44} \mathrm{~F}_{10} \mathrm{P}_{4} \mathrm{Pt}_{2}\right): \mathrm{C}, 51.44 ; \mathrm{H}, 2.88 ; M, 1540$. Found: $\mathrm{C}$, 51.39; H, 2.80. IR (Nujol, $\left.\mathrm{cm}^{-1}\right): v(\mathrm{CC}) 2079 \mathrm{~m} .{ }^{1} \mathrm{H}$ NMR $\left(\mathrm{C}_{6} \mathrm{D}_{6}\right)$ : $\delta 4.62\left(\mathrm{~m}, 4 \mathrm{H}, 2 \times \mathrm{CH}_{2}\right), 6.96-7.90(\mathrm{~m}, 40 \mathrm{H}, \mathrm{Ph}) .{ }^{19} \mathrm{~F}$ NMR: $\delta$ $-168.2(\mathrm{~m}, 2 \mathrm{~F}, m-\mathrm{F}),-165.7[\mathrm{t}, J(\mathrm{FF})=21 \mathrm{~Hz}, 1 \mathrm{~F}, p-\mathrm{F}],-143.1$ $(\mathrm{m}, 2 \mathrm{~F}, o-\mathrm{F}) .{ }^{31} \mathrm{P}$ NMR: $\delta 2.1$ [s, dppm, $\left.J(\mathrm{PtP})=2816 \mathrm{~Hz}\right]$. ES-MS $(\mathrm{MeOH}, m / z): 1541,[\mathrm{M}+\mathrm{H}]^{+}$.

\section{Derivatives of $\mathrm{Au}\left(\mathrm{C} \equiv \mathrm{CC}_{6} \mathrm{~F}_{5}\right)\left(\mathrm{PPh}_{3}\right)$}

\section{(a) $\mathrm{Mo}\left(\equiv \mathrm{CC} \equiv \mathrm{CC}_{6} \mathrm{~F}_{5}\right)(\mathrm{CO})_{2} \mathrm{Tp} *(5)$}

A mixture of $\mathrm{Au}\left(\mathrm{C} \equiv \mathrm{CC}_{6} \mathrm{~F}_{5}\right)\left(\mathrm{PPh}_{3}\right) \quad(60 \mathrm{mg}, 0.09 \mathrm{mmol})$, $\mathrm{Mo}(\equiv \mathrm{CBr})(\mathrm{CO})_{2} \mathrm{Tp}^{*}(50 \mathrm{mg}, 0.09 \mathrm{mmol}), \mathrm{Pd}\left(\mathrm{PPh}_{3}\right)_{4}(15 \mathrm{mg}$, $0.01 \mathrm{mmol})$ and $\mathrm{CuI}(5 \mathrm{mg}, 0.02 \mathrm{mmol})$ in thf $(10 \mathrm{ml})$ was stirred at r.t. for $2 \mathrm{~h}$. The solvent was then removed and the residue purified by preparative t.l.c. using acetone-hexane $(3: 7, \mathrm{v} / \mathrm{v})$ as eluent. The major fraction was collected as a green band which contained $\mathrm{Mo}\left(\equiv \mathrm{CC} \equiv \mathrm{CC}_{6} \mathrm{~F}_{5}\right)(\mathrm{CO})_{2} \mathrm{Tp}^{*}(\mathbf{5})(11 \mathrm{mg}, 18 \%)$. IR (Nujol, $\left.\mathrm{cm}^{-1}\right)$ : $v(\mathrm{CC}) 2110 \mathrm{w}, 2061 \mathrm{w}, v(\mathrm{CO}) 2006 \mathrm{~s}, 1926 \mathrm{s.}{ }^{1} \mathrm{H}$ NMR $\left(\mathrm{CDCl}_{3}\right)$ : $\delta 2.33(\mathrm{~s}, 6 \mathrm{H}, \mathrm{pz}-\mathrm{Me}), 2.38$ (s, 6H, pz-Me), 2.56 (s, 6H, pz-Me), $5.73\left(\mathrm{~s}, 1 \mathrm{H}, \mathrm{H}^{4}\right), 5.89\left(\mathrm{~s}, 2 \mathrm{H}, \mathrm{H}^{4}\right) .{ }^{13} \mathrm{C}$ NMR: $\delta 12.8,14.8,15.9$ (3×s, pz-CMe), 94.1, 108.9 ( $2 \mathrm{~s}, \mathrm{C} \equiv \mathrm{C}), 106.7 / 107.5,144.9 / 145.6$, $151.55 / 151.60(6 \times \mathrm{s}$, pz-ring C), $227.4(\mathrm{~s}, \mathrm{CO}), 248.8(\mathrm{~s}, \mathrm{Mo} \equiv \mathrm{C})$. 
${ }^{19} \mathrm{~F}$ NMR: $\delta-136.8(\mathrm{~m}, 2 \mathrm{~F}, o-\mathrm{F}),-153.7[\mathrm{t}, J(\mathrm{FF})=21 \mathrm{~Hz}, 1 \mathrm{~F}$, $p$-F], -163.9 (m, 2F, $m-\mathrm{F})$. ES-MS (MeOH + NaOMe, $m / z): 677$, $[\mathrm{M}+\mathrm{Na}]^{+} ; 487,\left[\mathrm{MC}_{6} \mathrm{~F}_{5}\right]^{+}$.

(b) $\mathrm{Co}_{3}\left(\boldsymbol{\mu}_{3}-\mathrm{CC} \equiv \mathrm{CC}_{6} \mathrm{~F}_{5}\right)(\boldsymbol{\mu}-\mathrm{dppm})(\mathbf{C O})_{7} \quad$ (6). A mixture of $\mathrm{Au}\left(\mathrm{C} \equiv \mathrm{CC}_{6} \mathrm{~F}_{5}\right)\left(\mathrm{PPh}_{3}\right) \quad(60 \mathrm{mg}, \quad 0.09 \mathrm{mmol}), \mathrm{Co}_{3}\left(\mu_{3}-\mathrm{CBr}\right)(\mu-$ dppm $)(\mathrm{CO})_{7}(30 \mathrm{mg}, 0.09 \mathrm{mmol}), \mathrm{Pd}\left(\mathrm{PPh}_{3}\right)_{4}(15 \mathrm{mg}, 0.01 \mathrm{mmol})$ and $\mathrm{CuI}(5 \mathrm{mg}, 0.02 \mathrm{mmol})$ in thf $(10 \mathrm{ml})$ was stirred at r.t. for $2 \mathrm{~h}$. Solvent was removed and the residue was purified by preparative t.l.c. (acetone-hexane, $3: 7, \mathrm{v} / \mathrm{v}$ ). The major fraction was collected as a brown-green band $\left(R_{\mathrm{f}}=0.52\right)$ to give $\mathrm{Co}_{3}\left(\mu_{3}-\mathrm{CC} \equiv \mathrm{CC}_{6} \mathrm{~F}_{5}\right)(\mu-\mathrm{dppm})(\mathrm{CO})_{7}(6)(10 \mathrm{mg}, 36 \%)$ as dark red crystals $\left(\mathrm{CH}_{2} \mathrm{Cl}_{2}\right.$ /pentane). Anal. Found: $\mathrm{C}, 51.30 ; \mathrm{H}, 2.25$. Calcd $\left(\mathrm{C}_{41} \mathrm{H}_{22} \mathrm{Co}_{3} \mathrm{~F}_{5} \mathrm{O}_{7} \mathrm{P}_{2}\right)$ : C, 51.28; $\mathrm{H}, 2.31 ; M, 960$. IR (Nujol, $\left.\mathrm{cm}^{-1}\right)$ : $v(\mathrm{CC}) 2122 \mathrm{w}, v(\mathrm{CO}) 2062 \mathrm{~s}, 2015 \mathrm{~s}, 1976(\mathrm{sh}) .{ }^{1} \mathrm{H} \mathrm{NMR}\left(\mathrm{CDCl}_{3}\right)$ : $\delta$ 3.49, $4.24\left(2 \mathrm{~m}, 2 \times 1 \mathrm{H}, \mathrm{CH}_{2}\right), 7.18-7.73(\mathrm{~m}, 20 \mathrm{H}, \mathrm{Ph}) \cdot{ }^{13} \mathrm{C}$ NMR: $\delta 29.6\left(\mathrm{~s}, \mathrm{CH}_{2}\right), 72.2(\mathrm{~s}, \mathrm{C} \equiv \mathrm{C}), 128.7-132.4\left(\mathrm{~m}, \mathrm{Ph}+\mathrm{C}_{6} \mathrm{~F}_{5}\right)$. ${ }^{19} \mathrm{~F}$ NMR: $\delta-139.8(\mathrm{~m}, 2 \mathrm{~F}, o-\mathrm{F}),-158.4[\mathrm{t}, J(\mathrm{FF})=21 \mathrm{~Hz}, 1 \mathrm{~F}$, $p$-F], -165.5 (m, 2F, $m$-F). ${ }^{31} \mathrm{P}$ NMR: $\delta 34.7$ (s, br, dppm). ES-MS $(\mathrm{MeOH}+\mathrm{NaOMe}, m / z): 982,[\mathrm{M}+\mathrm{Na}]^{+} ; 960, \mathrm{M}^{+}$.

(c) $\mathbf{F c C} \equiv \mathbf{C C} \equiv \mathbf{C C}_{6} \mathbf{F}_{5}$ (7). A mixture of $\mathrm{Au}\left(\mathrm{C} \equiv \mathrm{CC}_{6} \mathrm{~F}_{5}\right)\left(\mathrm{PPh}_{3}\right)$ (60 mg, $0.09 \mathrm{mmol}), \mathrm{IC} \equiv \mathrm{CFc}(30 \mathrm{mg}, 0.09 \mathrm{mmol}), \mathrm{Pd}\left(\mathrm{PPh}_{3}\right)_{4}$ $(15 \mathrm{mg}, 0.01 \mathrm{mmol})$ and $\mathrm{CuI}(5 \mathrm{mg}, 0.02 \mathrm{mmol})$ in thf $(10 \mathrm{ml})$ was stirred at r.t. for $2 \mathrm{~h}$. The solvent was then removed and the residue purified by preparative t.l.c. using acetone-hexane $(3: 7, \mathrm{v} / \mathrm{v})$ as eluent. The major fraction was collected as a bright orange band containing $\mathrm{FcC} \equiv \mathrm{CC} \equiv \mathrm{CC}_{6} \mathrm{~F}_{5}$ (7) (19 mg, 50\%). Anal. Calcd $\left(\mathrm{C}_{20} \mathrm{H}_{9} \mathrm{~F}_{5} \mathrm{Fe}\right): \mathrm{C}, 60.04 ; \mathrm{H}, 2.27 ; M$, 400. Found: C, 59.96; $\mathrm{H}$, 2.15. IR (Nujol, $\left.\mathrm{cm}^{-1}\right): v(\mathrm{CC}) 2220 \mathrm{~m} .{ }^{1} \mathrm{H}$ NMR $\left(\mathrm{C}_{6} \mathrm{D}_{6}\right): \delta 4.29$, $4.58\left(2 \times \mathrm{m}, 9 \mathrm{H}, \mathrm{Cp}+\mathrm{C}_{5} \mathrm{H}_{4}\right) \cdot{ }^{13} \mathrm{C} \mathrm{NMR}: \delta 62.1,69.5,86.9,99.6$ (4 s, C $\equiv \mathrm{C}), 70.4,70.8,72.9\left(3 \mathrm{~s}, \mathrm{C}_{5} \mathrm{H}_{4}\right), 132.3-137.5(\mathrm{~m}, \mathrm{Ph}) .{ }^{19} \mathrm{~F}$ NMR: $\delta-137.7(\mathrm{~m}, 2 \mathrm{~F}, o-\mathrm{F}),-153.9[\mathrm{t}, J(\mathrm{FF})=21 \mathrm{~Hz}, 1 \mathrm{~F}, p-\mathrm{F}]$, $-163.8(\mathrm{~m}, 2 \mathrm{~F}, m-\mathrm{F})$. ES-MS $(\mathrm{MeOH}, \mathrm{m} / z)$ : 400, $\mathrm{M}^{+}$. A minor band containing $\mathrm{FcC} \equiv \mathrm{CC} \equiv \mathrm{CFc}(7 \mathrm{mg}, 20 \%)$ was also obtained and identified by comparison with an authentic sample and from the ES-MS $(m / z$ 418).

\section{Derivatives of $1,4-\left(\mathrm{Me}_{3} \mathrm{SiC} \equiv \mathrm{C}\right)_{2} \mathrm{C}_{6} \mathrm{~F}_{4}$}

(a) 1,4- $\left\{\mathbf{C p}\left(\mathbf{P h}_{3} \mathbf{P}\right)_{2} \mathbf{R u}(\mathbf{C} \equiv \mathbf{C})\right\}_{2} \mathbf{C}_{6} \mathbf{F}_{4}$ (8). A mixture of 1,4$\left(\mathrm{Me}_{3} \mathrm{SiC} \equiv \mathrm{C}\right)_{2} \mathrm{C}_{6} \mathrm{~F}_{4}(24 \mathrm{mg}, 0.07 \mathrm{mmol}), \mathrm{RuCl}\left(\mathrm{PPh}_{3}\right)_{2} \mathrm{Cp}(100 \mathrm{mg}$, $0.14 \mathrm{~mol})$ and $\mathrm{KF}(8 \mathrm{mg}, 0.15 \mathrm{mmol})$ in thf $(5 \mathrm{ml})$ and $\mathrm{MeOH}$ $(20 \mathrm{ml})$ was heated under reflux for $5 \mathrm{~h}$. The resulting yellow precipitate was collected and washed with $\mathrm{MeOH}$ followed by hexane to give 1,4- $\left\{\mathrm{CpRu}\left(\mathrm{PPh}_{3}\right)_{2}(\mathrm{C} \equiv \mathrm{C})\right\}_{2} \mathrm{C}_{6} \mathrm{~F}_{4}(\mathbf{8})(66 \mathrm{mg}, 60 \%)$. Anal. Calcd $\left(\mathrm{C}_{92} \mathrm{H}_{70} \mathrm{P}_{4} \mathrm{Ru}_{2} \mathrm{~F}_{4}\right): \mathrm{C}, 70.04 ; \mathrm{H}, 4.47 ; M, 1578$. Found: C, 70.09; H, 4.47. IR (Nujol, $\mathrm{cm}^{-1}$ ): $v(\mathrm{CC}) 2073 \mathrm{~m}, 2039 \mathrm{~m} .{ }^{1} \mathrm{H}$ $\operatorname{NMR}\left(\mathrm{C}_{6} \mathrm{D}_{6}\right): \delta 4.86(\mathrm{~s}, 5 \mathrm{H}, \mathrm{Cp}), 6.94-7.75(\mathrm{~m}, 30 \mathrm{H}, \mathrm{Ph}) .{ }^{13} \mathrm{C}$ $\mathrm{NMR}\left(\mathrm{CDCl}_{3}\right): \delta 93.5(\mathrm{~s}, \mathrm{Cp}), 127.6-137.3(\mathrm{~m}, \mathrm{Ph}) .{ }^{19} \mathrm{~F}$ NMR $\left(\mathrm{C}_{6} \mathrm{D}_{6}\right): \delta-147.0\left(\mathrm{~s}, \mathrm{C}_{6} \mathrm{~F}_{4}\right) .{ }^{31} \mathrm{P}$ NMR $\left(\mathrm{C}_{6} \mathrm{D}_{6}\right): \delta 51.7\left(\mathrm{~s}, \mathrm{PPh}_{3}\right) . \mathrm{ES}-$ MS (MeCN, $m / z): 1578, \mathrm{M}^{+} ; 731,\left[\mathrm{Ru}(\mathrm{NCMe})\left(\mathrm{PPh}_{3}\right)_{2} \mathrm{Cp}\right]^{+} ; 691$, $\left[\mathrm{Ru}\left(\mathrm{PPh}_{3}\right)_{2} \mathrm{Cp}\right]^{+}$.

(b) $\quad \mathbf{1 , 4 -}\{\mathbf{C p}(\mathbf{d p p e}) \mathbf{R u}(\mathbf{C} \equiv \mathbf{C})\}_{2} \mathbf{C}_{6} \mathbf{F}_{4} \quad$ (9). As for $\mathbf{8}, \quad 1,4-$ $\left(\mathrm{Me}_{3} \mathrm{SiC} \equiv \mathrm{C}_{2} \mathrm{C}_{6} \mathrm{~F}_{4}(28 \mathrm{mg}, 0.08 \mathrm{mmol}), \mathrm{RuCl}(\mathrm{dppe}) \mathrm{Cp}\right.$ (100 mg, $0.17 \mathrm{mmol})$ and $\mathrm{KF}(9 \mathrm{mg}, 0.16 \mathrm{mmol})$ in thf $(5 \mathrm{ml})$ and $\mathrm{MeOH}$ (20 ml) gave yellow 1,4- $\{\mathrm{Cp}(\mathrm{dppe}) \mathrm{Ru}(\mathrm{C} \equiv \mathrm{C})\}_{2} \mathrm{C}_{6} \mathrm{~F}_{4}$ (9) $(28 \mathrm{mg}$, $26 \%$ ). Anal. Calcd $\left(\mathrm{C}_{72} \mathrm{H}_{58} \mathrm{P}_{4} \mathrm{Ru}_{2} \mathrm{~F}_{4} \cdot \mathrm{CHCl}_{3}\right): \mathrm{C}, 60.69 ; \mathrm{H}, 4.12 ; M$ (unsolvated), 1326. Found: C, 60.92; H, 4.11. IR (Nujol, $\mathrm{cm}^{-1}$ ): $v(\mathrm{CC}) 2072 \mathrm{~m}, 2037 \mathrm{~m} .{ }^{1} \mathrm{H}$ NMR $\left(\mathrm{C}_{6} \mathrm{D}_{6}\right): \delta 2.07,2.70(2 \mathrm{~m}$, $\left.2 \times 2 \mathrm{H}, \mathrm{CH}_{2} \mathrm{CH}_{2}\right), 4.71(\mathrm{~s}, 5 \mathrm{H}, \mathrm{Cp}), 6.91-7.99(\mathrm{~m}, 20 \mathrm{H}, \mathrm{Ph})$. ${ }^{13} \mathrm{C}$ NMR $\left(\mathrm{CDCl}_{3}\right): \delta 32.2\left(\mathrm{~m}, \mathrm{CH}_{2} \mathrm{CH}_{2}\right), 88.4(\mathrm{~s}, \mathrm{Cp}), 126.0$ $133.8(\mathrm{~m}, \mathrm{Ph}) .{ }^{19} \mathrm{~F}$ NMR $\left(\mathrm{C}_{6} \mathrm{D}_{6}\right): \delta-147.8\left(\mathrm{~s}, \mathrm{C}_{6} \mathrm{~F}_{4}\right) .{ }^{31} \mathrm{P} \mathrm{NMR}$ $\left(\mathrm{C}_{6} \mathrm{D}_{6}\right): \delta 86.7$ (s, dppe). ES-MS (MeCN, $\left.m / z\right): 1326, \mathrm{M}^{+} ; 605$, $[\mathrm{Ru}(\mathrm{NCMe})(\mathrm{dppe}) \mathrm{Cp}]^{+} ; 565,[\mathrm{Ru}(\mathrm{dppe}) \mathrm{Cp}]^{+}$.

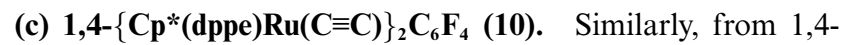
$\left(\mathrm{Me}_{3} \mathrm{SiC} \equiv \mathrm{C}\right)_{2} \mathrm{C}_{6} \mathrm{~F}_{4}(26 \mathrm{mg}, 0.07 \mathrm{mmol}), \mathrm{RuCl}(\mathrm{dppe}) \mathrm{Cp}^{*}$ (100 mg, $0.15 \mathrm{mmol})$ and $\mathrm{KF}(8 \mathrm{mg}, 0.15 \mathrm{mmol})$ in thf $(5 \mathrm{ml})$ and $\mathrm{MeOH}$ (20 ml) was obtained yellow $1,4-\left\{\mathrm{Cp}^{*}(\mathrm{dppe}) \mathrm{Ru}(\mathrm{C} \equiv \mathrm{C})\right\}_{2} \mathrm{C}_{6} \mathrm{~F}_{4}$ (10) (65 mg, 63\%). Anal. Calcd $\left(\mathrm{C}_{82} \mathrm{H}_{78} \mathrm{~F}_{4} \mathrm{P}_{4} \mathrm{Ru}_{2}\right): \mathrm{C}, 67.20 ; \mathrm{H}, 5.36 ; M$, 1466. Found: C, 67.21; H, 5.40. IR (Nujol, $\mathrm{cm}^{-1}$ ): $v(\mathrm{CC}) 2063 \mathrm{~m}$, $2032 \mathrm{~m} .{ }^{1} \mathrm{H}$ NMR $\left(\mathrm{C}_{6} \mathrm{D}_{6}\right): \delta 1.68(\mathrm{~s}, 15 \mathrm{H}, \mathrm{Cp} *), 1.99,2.88(2 \mathrm{~m}$, $\left.2 \times 2 \mathrm{H}, \mathrm{CH}_{2} \mathrm{CH}_{2}\right), 7.03-7.95(\mathrm{~m}, 20 \mathrm{H}, \mathrm{Ph}) .{ }^{13} \mathrm{C} \mathrm{NMR}\left(\mathrm{CDCl}_{3}\right): \delta$ 10.7 (s, $\left.\mathrm{C}_{5} M e_{5}\right), 30.1\left(\mathrm{~m}, \mathrm{CH}_{2} \mathrm{CH}_{2}\right.$ ), 93.7 (s, $C_{5} \mathrm{Me}_{5}$ ), 95.9 (s, br, $\mathrm{RuC}), 127.9-147.8(\mathrm{~m}, \mathrm{Ph}) .{ }^{19} \mathrm{~F}$ NMR $\left(\mathrm{C}_{6} \mathrm{D}_{6}\right): \delta-148.0\left(\mathrm{~s}, \mathrm{C}_{6} \mathrm{~F}_{4}\right)$. ${ }^{31} \mathrm{P}$ NMR $\left(\mathrm{C}_{6} \mathrm{D}_{6}\right): \delta 80.9$ (s, dppe). ES-MS $(\mathrm{MeCN}, \mathrm{m} / z): 1467$, $[\mathrm{M}+\mathrm{H}]^{+} ; 675,\left[\mathrm{Ru}(\mathrm{NCMe})(\mathrm{dppe}) \mathrm{RuCp}{ }^{*}\right]^{+} ; 635,\left[\mathrm{Ru}(\mathrm{dppe}) \mathrm{Cp}^{*}\right]^{+}$.

\section{Derivatives of $1,4-\left(\mathrm{Me}_{3} \mathrm{SiC} \equiv \mathrm{C}_{2} \mathrm{C}_{6} \mathrm{H}_{4}\right.$}

(a) 1,4- $\{\mathbf{C p}$ (dppe)Ru(C $\equiv \mathbf{C})\}_{2} \mathbf{C}_{6} \mathbf{H}_{4}$ (12). A mixture of 1,4$\left(\mathrm{Me}_{3} \mathrm{SiC} \equiv \mathrm{C}_{2} \mathrm{C}_{6} \mathrm{H}_{4}(50 \mathrm{mg}, 0.19 \mathrm{mmol}), \mathrm{RuCl}(\mathrm{dppe}) \mathrm{Cp}\right.$ (222 mg, $0.37 \mathrm{~mol})$ and $\mathrm{KF}(21 \mathrm{mg}, 0.37 \mathrm{mmol})$ in $\mathrm{MeOH}(30 \mathrm{ml})$ was heated under reflux for $16 \mathrm{~h}$. The yellow precipitate was collected and washed with $\mathrm{MeOH}, \mathrm{Et}_{2} \mathrm{O}$ and hexane to give 1,4- $\left\{\mathrm{Cp}(\mathrm{dppe}) \mathrm{Ru}(\mathrm{C} \equiv \mathrm{C}){ }_{2} \mathrm{C}_{6} \mathrm{H}_{4}\right.$ (12) $(69 \mathrm{mg}, 30 \%)$. Anal. Calcd $\left(\mathrm{C}_{72} \mathrm{H}_{62} \mathrm{P}_{4} \mathrm{Ru}_{2}\right): \mathrm{C}, 69.00 ; \mathrm{H}, 4.99 ; M, 1254$. Found: C, 68.98; H, 5.06. IR (Nujol, $\mathrm{cm}^{-1}$ ): $v(\mathrm{CC}) 2072 \mathrm{~m}, 2044$ (sh). ${ }^{1} \mathrm{H}$ NMR $\left(\mathrm{C}_{6} \mathrm{D}_{6}\right)$ : $\delta$ 1.96, $2.54\left(2 \mathrm{~m}, 2 \times 2 \mathrm{H}, \mathrm{CH}_{2} \mathrm{CH}_{2}\right), 4.26$ (s, 10H, Cp), 6.75$7.97\left(\mathrm{~m}, 44 \mathrm{H}, \mathrm{Ph}\right.$ and $\left.\mathrm{C}_{6} \mathrm{H}_{4}\right) \cdot{ }^{31} \mathrm{P}$ NMR: $\delta 87.0$ (s, dppe). ES-MS $(\mathrm{MeOH}+\mathrm{NaOMe}, m / z): 1277,[\mathrm{M}+\mathrm{Na}]^{+} ; 1255,[\mathrm{M}+\mathrm{H}]^{+}$.

(b) $1,4-\left\{C \mathbf{C}^{*}(\text { dppe }) \mathbf{R u}(\mathrm{C} \equiv \mathrm{C})\right\}_{2} \mathrm{C}_{6} \mathrm{H}_{4} \quad$ (13). A suspension of $\mathrm{RuCl}(\mathrm{dppe}) \mathrm{Cp}^{*}$ (500 mg, $\left.0.747 \mathrm{mmol}\right), 1,4-\left(\mathrm{Me}_{3} \mathrm{SiC} \equiv \mathrm{C}_{2} \mathrm{C}_{6} \mathrm{H}_{4}\right.$ (99 mg, $0.374 \mathrm{mmol})$, and KF (100 mg, $1.72 \mathrm{mmol})$ in methanol $(40 \mathrm{ml})$ was heated at reflux for $1 \mathrm{~h}$ under a nitrogen atmosphere. The yellow precipitate formed was collected and washed with $\mathrm{MeOH}$ and hexane and dried to give $\mathbf{1 3}$ as a yellow powder (390 mg, $0.280 \mathrm{mmol}, 75 \%$ ). Anal. Calcd $\left(\mathrm{C}_{78} \mathrm{H}_{82} \mathrm{P}_{4} \mathrm{Ru}_{2}\right)$ : C, 69.53; H, 6.09; M, 1346. Found: C, 69.17; H, 5.84. IR (Nujol, $\mathrm{cm}^{-1}$ ): $v(\mathrm{C} \equiv \mathrm{C}) 2067 \mathrm{~m}, 2046(\mathrm{sh}) .{ }^{1} \mathrm{H} \mathrm{NMR}\left(\mathrm{C}_{6} \mathrm{D}_{6}\right): \delta 1.63\left(\mathrm{~s}, 30 \mathrm{H}, \mathrm{Cp}^{*}\right)$; $1.85\left(\mathrm{~m}, 4 \mathrm{H}, \mathrm{CH}_{2}\right) ; 2.66\left(\mathrm{~m}, 4 \mathrm{H}, \mathrm{CH}_{2}\right) ; 7.02(\mathrm{~m}, 16 \mathrm{H}$, meta and para CH dppe), 7.10 (s, 4H, $\mathrm{CH} \mathrm{C}_{6} \mathrm{H}_{4}$ ), 7.12 (m, 8H, meta $\mathrm{CH}$ dppe), 7.19 (m, 8H, ortho $\mathrm{CH}$ dppe), 7.89 (m, 8H, ortho $\mathrm{CH}$ dppe). ${ }^{1} \mathrm{H}$ $\mathrm{NMR}\left(\mathrm{CDCl}_{3}\right): \delta 1.54\left(\mathrm{~s}, 30 \mathrm{H}, \mathrm{Cp}^{*}\right) ; 2.05\left(\mathrm{~m}, 4 \mathrm{H}, \mathrm{CH}_{2}\right) ; 2.70(\mathrm{~m}$, $\left.4 \mathrm{H}, \mathrm{CH}_{2}\right) ; 6.55\left(\mathrm{~s}, 4 \mathrm{H}, \mathrm{C}_{6} \mathrm{H}_{4}\right), 7.19(\mathrm{~m}, 8 \mathrm{H}, \mathrm{CH}$ dppe), $7.26(\mathrm{~m}$, $8 \mathrm{H}, \mathrm{CH}$ dppe), 7.33 (m, 16H, CH dppe), 7.89 (m, 8H, ortho $\mathrm{CH}$ dppe). ${ }^{31} \mathrm{P}$ NMR $\left(\mathrm{C}_{6} \mathrm{D}_{6}\right): \delta 82.1$ (s, dppe). ${ }^{31} \mathrm{P} \mathrm{NMR}\left(\mathrm{CDCl}_{3}\right): \delta$ 82.0 (s, dppe). ${ }^{13} \mathrm{C} \mathrm{NMR}\left(\mathrm{C}_{6} \mathrm{D}_{6}\right): 10.4\left(\mathrm{~s}, \mathrm{C}_{5} M e_{5}\right), 29.8\left(\mathrm{~m}, \mathrm{CH}_{2}\right)$, $92.6\left(\mathrm{~s}, C_{5} \mathrm{Me}_{5}\right), 111.5\left(\mathrm{~s}, \mathrm{C} \equiv \mathrm{CC}_{6} \mathrm{H}_{4}\right), 129.1,128.9\left(\mathrm{C}_{\mathrm{p}, \mathrm{p}^{\prime}}\right) ; 130.4$ $\left(\mathrm{CH}\right.$ in $\left.\mathrm{C}_{6} \mathrm{H}_{4}\right) ; 133.7,134.2\left(\mathrm{dds}, J_{\mathrm{CP} / \mathrm{CCP}} \sim 5 \mathrm{~Hz}, \mathrm{C}_{\mathrm{o}, \mathrm{o}^{\prime}}\right) ; 137.6,139.7$ $\left(\mathrm{m}, \mathrm{C}_{\mathrm{i}, \mathrm{i}^{\prime}}\right)$. The $\mathrm{C}_{\mathrm{m}, \mathrm{m}^{\prime}}$ dppe peak is assumed to be hidden by the $\mathrm{C}_{6} \mathrm{D}_{6}$ peak. The low intensity resonances corresponding to $\mathrm{Ru}-\mathrm{C}$ and one unique $\mathrm{C}$ of $\mathrm{C}_{6} \mathrm{H}_{4}$ were not observed. ES-MS $(\mathrm{MeOH}+$ $\mathrm{NaOMe}, m / z): 1369,[\mathrm{M}+\mathrm{Na}]^{+}$.

\section{Structure determinations}

Full spheres of CCD area-detector diffraction data were measured. $N_{\text {tot }}$ reflections were merged to $N$ unique ( $R_{\text {int }}$ cited) after 
"empirical"/multiscan absorption correction (proprietary software), $N_{\mathrm{o}}$ with $F>4 \sigma(F)$ being used in the full matrix least squares refinements on $F^{2}$. All data were measured using monochromatic Mo- $K \alpha$ radiation, $\lambda=0.7107_{3} \AA$. Anisotropic displacement parameter forms were refined for the non-hydrogen atoms, $(x$, $\left.y, z, U_{\text {iso }}\right)_{\mathrm{H}}$ being included following a riding model. Residuals $R$, $R_{\text {w }}$ on $F^{2}$ are quoted. Neutral atom complex scattering factors were used; computation used the XTAL 3.7 program system. ${ }^{47}$ Pertinent results are given in the figures (which show non-hydrogen atoms with $50 \%$ probability amplitude displacement ellipsoids and hydrogen atoms with arbitrary radii of $0.1 \AA$ ) and in Tables 1 and 2.

\section{Variata}

1. The solvent molecule (benzene) was modelled as disordered over two sets of sites, occupancy 0.5 .

2. $x_{\text {abs }}$ refined to $-0.07(5)$; refinement on $|F|$.

6. Refinement was carried out using the SHELXL 97 program. ${ }^{48}$

\section{Computations}

All DFT computations were carried out with the Gaussian 03 package. ${ }^{49}$ The model geometries 1-H, 1-F, 8-F and 11-H discussed here were optimised at the B3LYP/3-21G* level of theory, ${ }^{50}$ to reduce computational effort, with no symmetry constraints. Test calculations carried out with a larger basis set gave similar results, in a manner similar to that reported elsewhere. ${ }^{9}$ MOs and frequencies were computed on these optimised geometries at the same level of theory. All geometries were identified as minima (no imaginary frequencies). The barriers in the rotations between the aryl group and the $\mathrm{Ru}\left(\mathrm{PH}_{3}\right)_{2} \mathrm{Cp}$ groups in 1-H and 1-F were estimated by fixing the dihedral angles $\mathrm{P} 1-\mathrm{Ru}-\mathrm{C} 1-\mathrm{C} 2$ at $15^{\circ}$ intervals (see Fig. 1 for numbering scheme).

\section{Acknowledgements}

We thank Professor Brian Nicholson (University of Waikato, Hamilton, New Zealand) for providing the mass spectra and the ARC for support of this work and Johnson Matthey plc, Reading, for a generous loan of $\mathrm{RuCl}_{3} \cdot n \mathrm{H}_{2} \mathrm{O}$. These studies were facilitated by travel grants (ARC, Australia; the Royal Society of Chemistry, UK and the CNRS, France).

\section{References}

1 G. M. Brooke, J. Fluorine Chem., 1997, 86, 1.

2 R. D. Chambers, F. G. Drakesmith and W. K. R. Musgrave, J. Chem. Soc., 1965, 5045.

3 (a) R. D. Chambers, Fluorine in Organic Chemistry, Wiley: New York, 1973, ch. 9.II, p. 274; (b) G. Sandford, Philos. Trans. R. Soc. London, Ser. $A, 2000,358,455$.

4 (a) M. I. Bruce and F. G. A. Stone, J. Chem. Soc. A, 1966, 1837; (b) M. I. Bruce and F. G. A. Stone, Angew. Chem., 1968, 80, 835, (Angew. Chem., Int. Ed. Engl., 1968, 7, 747).

5 (a) O. M. Abu Salah and M. I. Bruce, J. Chem. Soc., Dalton Trans., 1975, 2311; (b) M. I. Bruce and R. C. Wallis, Aust. J. Chem., 1979, 32, 1471.

6 (a) M. I. Bruce, G. A. Koutsantonis, M. J. Liddell and B. K. Nicholson, J. Organomet. Chem., 1987, 321, 217; (b) M. I. Bruce, M. G. Humphrey and M. J. Liddell, J. Organomet. Chem., 1987, 321, 91; (c) M. I.
Bruce, M. G. Humphrey, G. A. Koutsantonis and M. J. Liddell, J. Organomet. Chem., 1987, 326, 247; (d) M. I. Bruce and M. G. Humphrey, Aust. J. Chem., 1989, 42, 1067.

7 (a) F. Paul, J.-Y. Mevellec and C. Lapinte, J. Chem. Soc., Dalton Trans., 2002, 1783; (b) K. Costuas, F. Paul, L. Toupet, J.-F. Halet and C. Lapinte, Organometallics, 2004, 23, 2053; (c) F. Paul, L. Toupet, J.-Y. Thépot, K. Costuas, J.-F. Halet and C. Lapinte, Organometallics, 2005, 24, 5464; (d) F. Paul, G. da Costa, A. Bondon, N. Gauthier, S. Sinbandhit, L. Toupet, K. Costuas, J.-F. Halet and C. Lapinte, Organometallics, 2007, 26, 874.

8 F. Paul, B. G. Ellis, M. I. Bruce, L. Toupet, T. Roisnel, K. Costuas, J.-F. Halet and C. Lapinte, Organometallics, 2006, 25, 649.

9 M. A. Fox, R. L. Roberts, W. M. Khairul, F. Hartl and P. J. Low, J. Organomet. Chem., 2007, $692,3277$.

10 (a) M. I. Bruce, P. J. Low, K. Costuas, J.-F. Halet, S. P. Best and G. A. Heath, J. Am. Chem. Soc., 2000, 122, 1949; (b) M. I. Bruce, B. D. Kelly, B. W. Skelton and A. H. White, J. Organomet. Chem., 2000, 604, 150; (c) M. I. Bruce, B. C. Hall, B. D. Kelly, P. J. Low, M. E. Smith, B. W. Skelton and A. H. White, J. Chem. Soc., Dalton Trans., 1999, 3719; (d) M. I. Bruce, B. G. Ellis, P. J. Low, B. W. Skelton and A. H. White, Organometallics, 2003, 22, 3184; (e) M. I. Bruce, K. Costuas, T. Davin, B. G. Ellis, J.-F. Halet, C. Lapinte, P. J. Low, M. E. Smith, B. W. Skelton, L. Toupet and A. H. White, Organometallics, 2005, 24, 3864.

11 F. Coat, P. Thominot and C. Lapinte, J. Organomet. Chem., 2001, 629, 39.

12 (a) M. I. Bruce, M. Ke and P. J. Low, Chem. Commun., 1996, 2405; (b) M. I. Bruce, M. Ke, P. J. Low, B. W. Skelton and A. H. White, Organometallics, 1998, 17, 3539.

13 R. Denis, T. Weyland, F. Paul and C. Lapinte, J. Organomet. Chem., 1997, 545-546, 615.

14 (a) R. Dembinski, T. Lis, S. Szafert, C. L. Mayne, T. Bartik and J. A. Gladysz, J. Organomet. Chem., 1999, 578, 229; (b) Q. Zheng and J. A. Gladysz, J. Am. Chem. Soc., 2005, 127, 10508.

15 (a) A. B. Antonova, M. I. Bruce, B. G. Ellis, M. Gaudio, P. A. Humphrey, M. Jevric, G. Melino, B. K. Nicholson, G. J. Perkins, B. W. Skelton, B. Stapleton, A. H. White and N. N. Zaitseva, Chem. Commun., 2004, 960; (b) A. B. Antonova, M. I. Bruce, P. A. Humphrey, M. Gaudio, B. K. Nicholson, N. Scoleri, B. W. Skelton, A. H. White and N. N. Zaitseva, J. Organomet. Chem., 2006, 691, 4694; (c) M. I. Bruce, M. E. Smith, N. N. Zaitseva, B. W. Skelton and A. H. White, J. Organomet. Chem., 2003, 670, 170; (d) M. I. Bruce, B. W. Skelton, A. H. White and N. N. Zaitseva, J. Organomet. Chem., 2003, 683, 398.

16 (a) T. X. Neenan and G. M. Whitesides, J. Org. Chem., 1988, 53, 2489; (b) P. Nguyen, Z. Yuan, L. Agocs, G. Lesley and T. B. Marder, Inorg. Chim. Acta, 1994, 220, 289.

17 P. Bladon, D. W. A. Sharp and J. M. Winfield, Spectrochim. Acta, 1964, 20, 1033.

18 M. I. Bruce, J. Chem. Soc. A, 1968, 1459.

19 P. G. Pringle and B. L. Shaw, J. Chem. Soc., Dalton Trans., 1983, 889.

20 M. J. Irwin, G. Jia, J. J. Vittal and R. J. Puddephatt, Organometallics, 1996, 15, 5321.

21 G. Eglinton and W. McCrae, Adv. Org. Chem., 1963, 4, 225.

22 M. S. Khan, M. R. A. Al-Mandhury, M. K. Al-Suti, T. C. Corcoran, Y. Al-Mahrooqi, J. P. Attfield, N. Feeder, W. I. F. David, K. Shankland, R. H. Friend, A. Köhler, E. A. Marseglia, E. Tedesco, C. C. Tang, P. R. Raithby, J. C. Collings, K. P. Roscoe, A. S. Batsanov, L. M. Stimson and T. B. Marder, New J. Chem., 2003, 27, 140.

23 (a) J. M. Wisner, T. J. Bartczak and J. A. Ibers, Inorg. Chim. Acta, 1985, 100, 115; (b) M. I. Bruce, M. G. Humphrey and M. R. Snow, J. Organomet. Chem., 1986, 314, 213.

24 M. I. Bruce, M. G. Humphrey, M. R. Snow and E. R. T. Tiekink, J. Organomet. Chem., 1986, 314, 213.

25 (a) A. J. Downard, B. H. Robinson and J. Simpson, Organometallics, 1986, 5, 1122; (b) A. J. Downard, B. H. Robinson and J. Simpson, J. Organomet. Chem., 1993, 447, 281.

26 M. I. Bruce, B. G. Ellis, M. Gaudio, C. Lapinte, G. Melino, F. Paul, B. W. Skelton, M. E. Smith, L. Toupet and A. H. White, Dalton Trans., 2004, 1601

27 G. Balavoine, J. Collin, J.-J. Bonnet and G. Lavigne, J. Organomet. Chem., 1985, 280, 429.

28 D. N. Duffy, M. M. Kassis and A. D. Rae, Acta Crystallogr., Sect. C, 1991, 47, 2054

29 (a) F.-E. Hong, Y.-L. Huang, Y.- C. Chang, K.-M. Chu and Y.-T. Tsai, Appl. Organomet. Chem., 2003, 17, 458; (b) F.-E. Hong, Y.-C. Lai, Y.-J. Ho and Y.-C. Chang, J. Organomet. Chem., 2003, 688, 161. 
30 (a) M. I. Bruce, K. A. Kramarczuk, G. J. Perkins, B. W. Skelton, A. H. White and N. N. Zaitseva, J. Cluster Sci., 2004, 15, 119; (b) M. I. Bruce, P. A. Humphrey, G. Melino, B. W. Skelton, A. H. White and N. N. Zaitseva, Inorg. Chim. Acta, 2005, 358, 1453; (c) M. I. Bruce, K. A. Kramarczuk, N. N. Zaitseva, B. W. Skelton and A. H. White, J. Organomet. Chem., 2005, 690, 1549; (d) M. I. Bruce, N. N. Zaitseva, P. J. Low, B. W. Skelton and A. H. White, J. Organomet. Chem., 2006, 691, 4273; (e) M. I. Bruce, M. L. Cole, M. Gaudio, B. W. Skelton and A. H. White, J. Organomet. Chem., 2006, 691, 4601.

31 C. Bitcon and M. W. Whiteley, J. Organomet. Chem., 1987, 336, 385.

32 I. R. Whittall, M. P. Ciuentes, M. G. Humphrey, B. Luther-Davis, M. Samoc, S. Houbrechts, A. Persoons, G. A. Heath and D. C. R. Hockless, J. Organomet. Chem., 549, 127.

33 T. Weyland, C. Lapinte, G. Frapper, M. J. Calhorda, J.-F. Halet and L. Toupet, Organometallics, 1997, 16, 2024.

34 A. Klein, O. Lavastre and J. Fiedler, Organometallics, 2006, 25, 635.

35 (a) S. E. Bailey, J. I. Zink and S. F. Nelson, J. Am. Chem. Soc., 2003, 125, 5939; (b) P. K. Sudeep, P. V. James, K. G. Thomas and P. V. Kamat, J. Phys. Chem. A, 2006, 110, 5642.

36 S. I. Ghazala, F. Paul, L. Toupet, T. Roisnel, P. Hapiot and C. Lapinte, J. Am. Chem. Soc., 2006, 128, 2463.

37 C. Creutz, Prog. Inorg. Chem., 1980, 30, 1.

38 (a) M. D. Ward and J. A. McCleverty, J. Chem. Soc., Dalton Trans., 2002, 275; (b) W. Kaim and G. K. Lahiri, Angew. Chem., Int. Ed., 2007, 46, 1778.

39 W. Henderson, J. S. McIndoe, B. K. Nicholson and P. J. Dyson, J. Chem. Soc., Dalton Trans., 1998, 519.

40 M. I. Bruce, B. C. Hall, P. J. Low, B. W. Skelton and A. H. White, J. Organomet. Chem., 1999, 592, 74.

41 A. G. Alonso and L. B. Reventós, J. Organomet. Chem., 1988, 338, 249.

42 M. I. Bruce, C. Hameister, A. G. Swincer and R. C. Wallis, Inorg. Synth., 1990, 28, 270.
43 F. J. Lalor, T. J. Desmond, G. M. Cotter, C. A. Shanahan, G. Ferguson, M. Parvez and B. Ruhl, J. Chem. Soc., Dalton Trans., 1995, 1709.

44 D. R. Coulson, Inorg. Synth., 1990, 28, 107.

45 M. I. Bruce, M. E. Smith, B. W. Skelton and A. H. White, Aust. J. Chem., 1999, 52, 431.

46 M. I. Bruce, E. Horn, J. G. Matisons and M. R. Snow, Aust. J. Chem., 1984, 37, 1163.

47 S. R. Hall, D. J. du Boulay and R. Olthof-Hazekamp, (eds), The XTAL 3.7 System, University of Western Australia, 2000.

48 G. M. Sheldrick, SHELXL97: A Program for Crystal Structure Refinement, University of Gottingen, 1997.

49 Gaussian 03, Revision C.02, M. J. Frisch, G. W. Trucks, H. B. Schlegel, G. E. Scuseria, M. A. Robb, J. R. Cheeseman, J. A. Montgomery, Jr., T. Vreven, K. N. Kudin, J. C. Burant, J. M. Millam, S. S. Iyengar, J. Tomasi, V. Barone, B. Mennucci, M. Cossi, G. Scalmani, N. Rega, G. A. Petersson, H. Nakatsuji, M. Hada, M. Ehara, K. Toyota, R. Fukuda, J. Hasegawa, M. Ishida, T. Nakajima, Y. Honda, O. Kitao, H. Nakai, M. Klene, X. Li, J. E. Knox, H. P. Hratchian, J. B. Cross, C. Adamo, J. Jaramillo, R. Gomperts, R. E. Stratmann, O. Yazyev, A. J. Austin, R. Cammi, C. Pomelli, J. W. Ochterski, P. Y. Ayala, K. Morokuma, G. A. Voth, P. Salvador, J. J. Dannenberg, V. G. Zakrzewski, S. Dapprich, A. D. Daniels, M. C. Strain, O. Farkas, D. K. Malick, A. D. Rabuck, K. Raghavachari, J. B. Foresman, J. V. Ortiz, Q. Cui, A. G. Baboul, S. Clifford, J. Cioslowski, B. B. Stefanov, G. Liu, A. Liashenko, P. Piskorz, I. Komaromi, R. L. Martin, D. J. Fox, T. Keith, M. A. Al-Laham, C. Y. Peng, A. Nanayakkara, M. Challacombe, P. M. W. Gill, B. Johnson, W. Chen, M. W. Wong, C. Gonzalez, and J. A. Pople, Gaussian, Inc., Wallingford CT, 2004.

50 (a) A. D. Becke, J. Chem. Phys., 1993, 98, 5648; (b) C. Lee, W. Yang and R. G. Parr, Phys. Rev. B, 1988, 37, 785; (c) G. A. Petersson and M. A. Al-Laham, J. Chem. Phys., 1991, 94, 6081; (d) G. A. Petersson, A. Bennett, T. G. Tensfeldt, M. A. Al-Laham, W. A. Shirley and J. Mantzaris, J. Chem. Phys., 1988, 89, 2193. 